Author version: J. Sediment. Res., vol.83(6); 2013; 427-442

\title{
Geochemical and Isotopic Signatures of Surficial Sediments from the Western Continental Shelf of India: Inferring Provenance, Weathering and the Nature of Organic Matter
}

\author{
SIBY KURIAN $^{1 *}$, B. NAGENDER NATH ${ }^{1}$, N. CHANDRAMOHANA KUMAR ${ }^{2}$ AND K.K.C. NAIR ${ }^{3}$ \\ ${ }^{1}$ National Institute of Oceanography (Council of Scientific and Industrial Research), Dona Paula, Goa- 403 004, India \\ ${ }^{2}$ Department of Chemical Oceanography, Cochin University of Science and Technology, Cochin-682 016, India \\ ${ }^{3}$ National Institute of Oceanography (Council of Scientific and Industrial Research), Regional Centre, Kochi - 682018, India \\ ${ }^{*}$ Corresponding author, E-mail: siby@nio.org \\ Phone: 91-832 2450399; Fax: 91-832-2450607
}

\begin{abstract}
Bottom sediments from thirteen transects mainly sampled at depth contours of 30, 100 and 200m along the western continental margin of India, falling in two offshore sectors from Dwaraka to Goa and Cape Comorin to Goa were analysed for calcium carbonate, major elements in silicate fraction, trace and rare earth elements in the bulk fraction, and carbon and nitrogen isotopes in organic matter to understand the provenance of sediments, weathering patterns in the source areas and nature of organic matter. Major elements such as $\mathrm{Si}, \mathrm{Ti}, \mathrm{Mg}$ and discrimination plots involving alkalies and silica have shown a distinct north-south provinciality with the source signatures pointing at Deccan basalt for sediments in north (from Dwaraka to Goa) and gneisses and granulites of South India in south. Shale normalized REE patterns and REE content suggest additional local sources mainly in the southwest coast of India. Degree of alteration determined using Chemical Index of Alteration (CIA), Plagioclase Index of Alteration (PIA), A-CN-K plots have suggested that the sediments are moderately weathered despite the intense orographic rainfall in the source area. Variability in degree of chemical weathering is seen with the change in provenance. In general, the sediments north of Goa with a provenance of Deccan basalts show higher chemical weathering index. $\mathrm{C}_{\text {org }} / \mathrm{N}$ molar ratios (range $=6.9$ and 14) are mostly between 10 and 12 which are closer to marine organic matter values. This is corroborated by marine $\delta^{13} \mathrm{C}$ values $(-18.2$ to $-21.6 \%$ ). While, they broadly fall within the marine values, heavier values are seen in northern transects off Porbandar and Dwaraka where the sediments have a provenance different from those in the south. This could be due to a higher contribution from C-4 type vegetation in the north, consistent with heavier $\delta^{13} \mathrm{C}$ values in terrestrial plants in source regions. Comparatively heavier $\delta^{15} \mathrm{~N}$ values are observed for the northern transects (north of Ratnagiri) which is supported by the intense denitrification in the northern Arabian Sea.
\end{abstract}

\section{Key words:}

Eastern Arabian Sea, sediment geochemistry, provenance, weathering, $\mathrm{C}$ and $\mathrm{N}$ isotopes 


\section{INTRODUCTION}

Continental margins cover only about 7-9\% of the world ocean area (Legeleux et al. 1994 and references therein; Nath et al. 1997), but play an important role in ocean biogeochemistry due to rich riverine inputs, strong physical forcing (such as upwelling), high biological productivity and active benthic processes (e.g. Kao et al. 2006 and references therein). Consequently, their collective contribution to the marine carbon cycle is drawing increasing attention (Ducklow and McCallister 2004; Kao et al. 2006). Rivers with high fluvial sediment discharges are located in Asia and Oceania (Milliman and Meade 1983; Milliman and Syvitski 1992). River sourced sediments are deposited in the continental shelves and much if not most of the sediment transported to broad passive margin shelves remains on the inner to middle portions of the shelves. Along with the high fluvial sediment discharges, organic carbon can be efficiently trapped in these continental margins due to the rapid sedimentation that helps transportation as well as preservation of organic carbon. Eastern Arabian Sea has all these traits such as the high fluvial sediment supply from Indus, Narmada, Tapti and several small rivers in central and south India, and it is one of the highly productive areas in the world mainly due to the high nutrient concentrations from the freshly upwelled water during south west monsoon, and due to winter convection during north east monsoon, and consequently has high organic matter accumulation (Madhupratap et al. 1996).

Enhanced oxygen demand due to respiration of organic matter in the semi enclosed basin results in $\mathrm{O}_{2}$ deficiency (up to $<0.1 \mathrm{ml} / \mathrm{L}$ ) at a depth of $150-1000 \mathrm{~m}$ in the northwestern Indian Ocean (Wyrtki 1971; Naqvi 1987; Naqvi et al. 2006). This makes the Arabian Sea, along with eastern tropical North Pacific (ETNP) and eastern tropical South Pacific (ETSP) as one of the three major regions in the open ocean having suboxic (=denitrifying) intermediate waters. Water column denitrification (conversion of nitrate to elemental nitrogen) in these oxygen deficient zones (ODZs) result large $\mathrm{N}$ isotopic fractionation preferentially converting ${ }^{14} \mathrm{~N}$ into $\mathrm{N}_{2}$ and leaving the residual $\mathrm{NO}_{3}{ }^{-}$enriched with ${ }^{15} \mathrm{~N}$. In addition to the perennial open ocean oxygen minimum zone (OMZ), Arabian Sea also experiences seasonal OMZ in the coastal waters which undergo intensification during recent years due to both the natural and anthropogenic reasons such as land use changes, enhanced fertilizer loading etc. (Naqvi et al. 2000). Thus, eastern Arabian Sea is an interesting area to study the sediment chemistry in coastal and shelf regions. Among the earliest geochemical studies on the sediments from the continental margin of India, Murty et al. (1970; 1973 and several others) concentrated on partitioning the distribution of major and minor elements between the lithogenic and non-lithogenic fractions, Marchig (1972) identified two main facies viz., coarse grained rich in $\mathrm{Fe}$ and $\mathrm{Ti}$ in shelf and upper slope and clay-mineral rich fine grained facies (rich in $\mathrm{Mn}, \mathrm{Ni}, \mathrm{Cu}$ and $\mathrm{Zn}$ ) in lower slope and deep ocean. While the geochemical maps of selected elements were prepared by Paropkari et al. (1994) for the western continental shelf of India, Shankar et al. (1987) to our knowledge were the first to map the major geochemical provinces of the

Arabian Sea. Variability of sediment REEs and trace elements in a transect across the continental margin and their response to the bottom water oxygenation conditions was presented by Nath et al. (1997). 
Here, we have studied fifty surface sediment samples from the western continental shelf of India covering thirteen transects of three depth contours (30,100, and 200m below sea-level) from Cape Comorin (southern tip of India) to Dwaraka in north. A comprehensive study based on a set of geochemical parameters including all rock-forming major elements in lithogenic fraction, trace and rare earth elements (REEs), calcium carbonate $\left(\mathrm{CaCO}_{3}\right)$, organic carbon $\left(\mathrm{C}_{\text {org }}\right)$ and nitrogen content, and the isotope composition of $\mathrm{C}_{\text {org }}$ and $\mathrm{N}$ is undertaken with the objectives to decipher the sediment provenance, weathering at source, dispersal pattern, nature of organic matter and the influence of water column chemistry on stable isotopes in sediments. Three major sources of sediments viz., those derived from River Indus, erosional products of Deccan Traps and gneissic rocks, have been identified earlier along the western continental margin of India (Mattait et al. 1973; Nair et al. 1982a) and later confirmed from clay mineral (Rao and Rao 1995) and radiogenic isotope studies (Kessarkar et al. 2003). In this paper, we use refractory and rare earth elements (which are robust indicators of provenance) to study the source as well as the dispersal patterns of lithogenic sediments. We also try to understand the weathering patterns in the source terrains of west coast of India based on geochemical alteration indices, as some of the adjacent coastal landmasses receive large rainfall during south west monsoon. In addition, the chemical studies of clays undertaken in the past has shown that parts of west coast of India may have witnessed intense chemical weathering (Nath et al. 2000). While the papers in late eighties and nineties have debated on the depositional controls on the organic matter distribution in the Arabian Sea (Pedersen et al. 1992; Paropkari et al. 1993; Calvert et al. 1995; van der Weijden et al. 1999; Rao and Veerayya 2000; Cowie 2005), here we made an attempt to understand the nature of organic matter by analyzing $\mathrm{C}_{\mathrm{org}} / \mathrm{N}$ ratios and $\delta^{13} \mathrm{C}$ values. Water column denitrification is prominent in the northern Arabian Sea as compared to southern region (Naqvi 1987). Our intention was to see if this north-south change in water column denitrification is reflected in the nitrogen isotopic composition of to the underlying sediments. This study on surficial sediments representing the present day ocean processes would help to identify the past records of denitrification in the area.

\section{Oceanographic and geological settings of the study area}

The Arabian Sea is a semi enclosed basin surrounded by arid landmasses to the west and north and by coastal highlands of western India to the east. There is no outlet to the north, but the basin waters and sediments are influenced by inflow from Persian Gulf and the Red Sea and by exchange across the equator (Wyrtki 1971). It also experiences extreme atmospheric forcing that leads to the greatest seasonal variability observed in any ocean basin. Monsoons are the seasonally reversing winds, which bring rain to the Indian subcontinent and cause upwelling along the continental margins. This seasonal reversal of the wind direction between summer and winter drives the south west (SW) and north east (NE) monsoons in the Indian Ocean and precipitation over south Asia.

The width of the western continental shelf of India is about $130 \mathrm{~km}$ off Ratnagiri and narrows down to $80 \mathrm{~km}$ off Cochin (Rao and Rao 1995). It is again wider $(120 \mathrm{~km})$ at the southern tip of India, off Cape Comorin. Rivers especially Indus, Narmada, Tapti, Sabarmati and Mahi are the major sources of terrigenous sediments to the eastern Arabian Sea. The Indus fan is one of the largest submarine fans in 
the world. Western Ghat mountain ranges are composed of two major rock types: the Deccan Trap basalts between Tapti and Mormugao and Precambrian gneisses and schists between Mormugao and Cape Comorin (Nair et al. 1982a). Nair and Pylee (1968), Hashimi et al. (1982) reported that two distinct sediment types occur on the western continental shelf of India: modern clastic clays on the inner shelf and relict sandy sediments on the outer shelf (Fig. 1a). Terrigenous sediments mostly occur as sands in the near shore (upto 10-12 m water depth) followed by a zone of silty clays on the inner shelf between Saurashtra and Quilon (Kollam) (Rao and Wagle, 1997). The outer shelf sediments are Holocene carbonate sands between Ratnagiri and Mangalore and are terrigenous sands between Mangalore and Cochin. The continental shelf between Quilon and Cape Comorin does not contain clay zone $(<2 \%)$ unlike the rest of the inner shelf (between Saurashtra and Quilon). It consists of biogenic carbonate sands. Absence of clay zone has been attributed to the scarcity of estuaries in this region (Hashimi and Nair 1986) and to coastal rock formations and hydrodynamic factors influenced by coastal configurations (Rao and Wagle 1997).

\section{MATERIALS AND METHODS}

\section{Sample collection}

The surface sediment samples were collected using Van veen grab from the western continental shelf of India, during the $162^{\text {nd }}$ cruise of FORV (Fisheries and Oceanographic Research Vessel) Sagar Sampada (February $16^{\text {th }}$ to March $6^{\text {th }}, 1998$ ) under MLR (Marine Living Resources) benthic program (sponsored by Ministry of Earth Sciences, New Delhi). Bottom water samples were also collected at each station. Dissolved oxygen (DO) was analyzed onboard following Winkler method (Grasshoff et al. 1983). 50 surface sediment samples were collected along 13 transects (off Cape Comorin to Dwaraka) from the west coast of India (Fig. 1b) and the details are listed in Table 1. The sediments were collected mainly from 3 depth contours viz. $30 \mathrm{~m}, 100 \mathrm{~m}$ and $200 \mathrm{~m}$.

\section{$\mathrm{CaCO}_{3}$, major and minor elements and $\mathrm{REES}$}

Dried sediments were homogenised and $\mathrm{CaCO}_{3}$ content was determined using Coulometer as well as with modified carbonate bomb method (Müller and Gastner 1971). Replicate analysis of samples and standards showed that the analytical reproducibility was better than $5 \%$ of the measured value. The major elements were analysed using X-ray Fluorescence Spectrometer (XRF, PANalytical AXIOS) at National Institute of Oceanography (NIO) mainly in lithogenic fraction free of carbonate and sea salts. Samples were washed repeatedly to remove sea salts while decalcification was done using $20 \%$ acetic acid and followed by washing. Silver nitrate was added to supernatant water after each wash, and if white precipitate still persisted (indicating the presence of chloride), more water was added to wash the salt. Each time, they were centrifuged to decant the supernatant to avoid the loss of fines. For complete carbonate removal, the acid was allowed to react with sediments until the bubbling $\left(\mathrm{CO}_{2}\right.$ release $)$ stops. The analyses were carried out on glass beads made using $0.55 \mathrm{~g}$ of decalcified, powdered sediment fluxed with $5.5 \mathrm{~g}$ dilithium tetraborate, $0.07 \%$ Li bromide (Merck). The accuracy and precision of analysis was checked with geochemical standard, JMS-1 (Geological Survey of Japan, Marine sediment- 
1) and given in Table 2. Trace and rare earth elements were analysed by ICP-MS at National Geophysical Research Institute (NGRI), Hyderabad after digesting 50mg sediment with $\mathrm{HF}, \mathrm{HNO}_{3}$ and $\mathrm{HClO}_{4}$ (6:3:1 ratio) in Teflon beakers (open digestion) (Balaram and Rao 2002; Mascarenhas-Pereira and Nath 2010). Rhodium (5ml; 1ppm) was added as internal standard and the final solutions were made up in $\mathrm{HNO}_{3}$ medium. Marine Mud sediment standard (MAG-1) of United States Geological Survey was analysed along with the samples for determining the accuracy. Precision of the analyses was calculated from duplicate and triplicate analyses of standard and some of the samples. The values obtained for certified standards by us along with accuracy and precision data are presented in Table 2. For comparison, recommended values for MAG-1 (Govindaraju, 1994) and those obtained recently by Nath et al. (2009) are also presented (Table 2). Accuracy is better than $\pm 1 \%$ for elements $\mathrm{La}, \mathrm{Ce}, \mathrm{Yb}, \mathrm{Ba}, \mathrm{Nb}$, $\pm 2 \%$ for elements $\mathrm{Rb}, \mathrm{Sm}, \mathrm{Hf}, \pm 3 \%$ for elements $\mathrm{Ga}, \mathrm{Pr}, \mathrm{Nd}, \mathrm{Dy}, \mathrm{Er}, \mathrm{Sr}, \mathrm{Zr}, \mathrm{Hf}, \pm 4 \%$ for elements $\mathrm{Sc}$, $\mathrm{Tb}, \mathrm{Ho}, \mathrm{Lu}, \mathrm{Th}, \mathrm{Ta}, \pm 5 \%$ for elements $\mathrm{Gd}, \mathrm{U}$ and $\pm 6 \%$ for elements $\mathrm{Eu}$ and $\mathrm{Tm}$. We have shown bulk geochemical data in the tables, but due to large variability in $\mathrm{CaCO}_{3}$ content, trace and REE concentration are calculated on a carbonate-free basis $(c f b)$ using the following equation and used in certain figures and calculation of fractionation indices to represent the lithogenic fraction.

$\mathrm{El}{ }_{(c f b)}=(\mathrm{El} * 100) /\left(100-\mathrm{CaCO}_{3} \%\right)$ where El represents the concentration of a given element and $\mathrm{El}_{(c f b)}$ representing elemental concentration on a carbonate-free basis. Ce anomaly is defined as $\mathrm{Ce} / \mathrm{Ce}^{*}$ (values with respect to shale), where $\mathrm{Ce}$ is $\mathrm{Ce}_{\text {sample }} / \mathrm{Ce}_{\mathrm{PAAS}}$ and $\mathrm{Ce}$ * is the predicted value obtained by linear interpolation between shale-normalized $\mathrm{La}$ and $\mathrm{Pr}$ values. Similarly, Eu anomaly $\left(\mathrm{Eu} / \mathrm{Eu}^{*}\right)$ is calculated using the concentrations of Sm, Eu and Gd (e.g., Nath et al. 1997).

\section{$C$ and $N(\%)$ and stable isotopic analysis}

For measurement of $\mathrm{C}_{\text {org }}$ and $\mathrm{N}$ content and their isotopic ratios, samples were decalcified using $1 \mathrm{~N} \mathrm{HCl,}$ washed thoroughly with deionized water and dried. ${ }^{13} \mathrm{C} /{ }^{12} \mathrm{C}$ ratio and ${ }^{15} \mathrm{~N} /{ }^{14} \mathrm{~N}$ ratio together with $\mathrm{C}_{\text {org }}$ and $\mathrm{N}$ content were measured using an Isotope Ratio Mass-Spectrometer (Delta V plus; ${ }^{\circledR T h e r m o)}$ coupled with an Elemental Analyzer (EA) in a continuous flow mode at the National Institute of Oceanography, Goa. The details of analytical procedures are given in Agnihotri et al. (2008) and Maya et al. (2011). Reference gases were calibrated relative to the international standards IAEA N1 $\left(\delta^{15} \mathrm{~N}=\right.$ $+0.4 \%)$ and $\mathrm{N} 2\left(\delta^{15} \mathrm{~N}=+20.3 \%\right)$ for nitrogen and USGS-40 $\left(\delta^{13} \mathrm{C}=-26.389 \%\right)$ for carbon. Calibrations for $\mathrm{C}_{\text {org }}$ and $\mathrm{N}$ content and their isotopes were carried out using a laboratory standard (n-Caprioic acid, $\mathrm{C}_{6} \mathrm{H}_{15} \mathrm{NO}_{2}$; ACA $\left(\delta^{15} \mathrm{~N}=+4.6 \%\right.$ and $\delta^{13} \mathrm{C}=-25.3 \%$ ) following Higginson and Altabet (2004). Carbon and nitrogen content in the unknown samples were calculated from a calibration curve made of ACA standards ranging from 1 to $4 \mu \mathrm{M}$ for nitrogen and 6 to $24 \mu \mathrm{M}$ for carbon (see Maya et al. 2011 for a description of the method followed). Analytical precision was better than $2 \%$ for $\mathrm{C}_{\text {org }}$ and $\mathrm{N}$ content. Carbon and nitrogen isotopic ratios of sedimentary organic matter are expressed as $\delta$ values $\left(\delta^{13} \mathrm{C}_{\text {org }}\right.$ and $\delta^{15} \mathrm{~N}$ ) with reference to $\mathrm{V}-\mathrm{PDB}$ and atmospheric $\mathrm{N}_{2}$ respectively.

$$
\delta^{13} \mathrm{C}_{\text {org }} \text { and } \delta^{15} \mathrm{~N} \%=\left(\left(\mathrm{R}_{\text {sample }}-\mathrm{R}_{\text {standard }}\right) / \mathrm{R}_{\text {standard }}\right) \times 1000
$$


where $\mathrm{R}={ }^{13} \mathrm{C} /{ }^{12} \mathrm{C}$ and ${ }^{15} \mathrm{~N} /{ }^{14} \mathrm{~N}$. Standard deviation $(1 \sigma)$ for both ${ }^{13} \mathrm{C}$ and ${ }^{15} \mathrm{~N}$ was less than $0.2 \%$ (for $\mathrm{n}$ $=10$ samples).

\section{RESULTS}

The thirteen transects along the western continental margin are divided into two offshore sectors viz, 1) Cape Comorin to Goa and 2) Goa to Dwaraka based on previous studies. Dissolved oxygen concentrations of bottom waters at the sampling locations are given in Table 1. Dissolved oxygen in the bottom waters showed a sharp decrease in concentration with depth. It varied from $3.7 \mathrm{ml} / \mathrm{L}$ at $30 \mathrm{~m}$ depth to $<0.1 \mathrm{ml} / \mathrm{L}$ at a depth of $200 \mathrm{~m}$ depth (Table 1). Deeper stations $(200 \mathrm{~m})$ which fall in the OMZ experience suboxic values in the bottom waters especially in northern transects (Qasim 1982; Sengupta et al. 1976).

Major elements in lithogenic fraction, REEs and trace elements are presented in Table 3 and Table 4 respectively. $\mathrm{SiO}_{2}$ showed higher values for samples south of Goa (average 76\%) compared to those in northern transects average 55.3\%). In contrast, $\mathrm{TiO}_{2}$ and $\mathrm{MgO}$ showed low values for samples south of Goa and high concentration for the northern transects (Fig. 1c).

Thorium and REEs showed enhanced values along the south west coast of India (KOLLAM and KOCHI) compared to northern transects (Table 4). ¿REEs varied between 14 and 194 ppm with higher concentration for the coastal samples (30m depths) compared to the offshore sediments, except in two transects (Table 4). REEs are normalized with Post Archaean Australian Shale (PAAS) (values from McLennan 1989, which are modified from Taylor and McLennan 1985) and the transect-wise shale normalized patterns are shown in Fig. 2. Ce and Eu anomalies and fractionation indices are calculated following Nath et al. (1997 and references therein) and shown in Table 5. In general, no Ce anomaly was observed for the coastal samples while certain offshore samples (CAPE COM, TVM, GOA, RAT and VER) showed negative $\mathrm{Ce}_{\text {ano }}$ ( $\sim 0.7$ to 0.8$)$.. Most of the samples showed positive Eu anomaly (1.3 to 1.6), except one sample (CAPE COM) which had negative $\mathrm{Eu}_{\text {ano }}(0.8)$. Fractionation index of light to heavy REEs $\left((\mathrm{La})_{\mathrm{n}} /(\mathrm{Yb})_{\mathrm{n}}\right.$ showed higher values $(2-3)$ for the southern transects (KOLLAM and KOCHI) with LREE enrichment (Table 5), while HREE enrichment was observed for the sediments from central west coast of India (MNG, GOA, RAT and MUM).

$\mathrm{CaCO}_{3}$ content is generally higher (70-93\%, Table 6) in sediments from $100 \mathrm{~m}$ depth. $\mathrm{C}_{\text {org }}$ and $\mathrm{N} \%$ showed wide range of variability for samples along the western continental shelf of India $(0.13-3.5 \%$ and $0.02-0.37 \%$ respectively, Table 6). $\mathrm{C} / \mathrm{N}_{\text {molar }}$ ratios ranged between 6.9 and 14 and the $\delta^{13} \mathrm{C}$ values varied between -21.7 and $-18 \%$. $\delta^{15} \mathrm{~N}$ ranged between 4.6 and $9.1 \%$ with higher values for the northern transects (Table 6). 


\section{DISCUSSION}

\section{Deciphering the sediment provenance}

Major elements in lithogenic fraction and the discrimination plots of their oxides are employed here to discern the sediment provenance and the degree of weathering (Nesbitt and Young 1982; Le Maitre et al. 1989; McLennan 1989; Wronkiewicz and Condie 1990; Fedo et al. 1995; Nath et al. 2000). Also used are the relative abundance of trace and REEs in sediments, elemental ratios, shale normalized REE patterns, chondritenormalized spidergram, and the ternary diagrams (McLennan 1989; Morey and Setterholm 1997; Nath et al. 1992; 1997; Siby 2004).

\section{Major elements.-}

Latitudinal distribution of major element oxides viz., $\mathrm{SiO}_{2}, \mathrm{TiO}_{2}$ and $\mathrm{MgO}$ along the inshore transect (30m and 50m depths) are plotted (Fig. 1c) alongside published maps (Kessarkar et al. 2003 and references therein) of geology of source terrains (Fig. 1b) and sediment type distribution in the western continental margin of India (Fig. 1a). Elements Si, Ti and Mg are considered diagnostic in view of their large differences in content in sediments derived from felsic and basic rocks. On a broader scale, a distinct north-south provinciality is seen separating Si-low (mean $\mathrm{SiO}_{2}=55.3 \%$; Table 3), and Ti-Mg rich (mean for oxides $=1.61$ and $2.53 \%$ respectively) sediments in the north from those rich in $\mathrm{SiO}_{2}$ (mean=76\%) and poor in $\mathrm{Ti}$ and Mg-oxides in south (mean $=1.05$ and $0.96 \%$ ). This distinct provinciality is solidly consistent with the source terrain geology (Fig. 1b). Si-poor and Ti-Mg rich sediments north of Goa closely correspond with Deccan Trap basaltic terrain on land and those in south of Goa are juxtaposed with granulitic terrain composed of rocks such as gneisses, charnockites etc. Here, we show a close correspondence between the composition of shelf sediments and the geology of adjacent land in the Arabian Sea. Provinciality was reported earlier based on clay mineral studies. On the basis of different clay mineral assemblages or clay mineral ratios (smectite (S)/illite (I) and kaolinite $(\mathrm{K}) /$ chlorite $(\mathrm{Ch})$ ) of the sediments and major rock types in the drainage basins of the rivers, three major sources of sediments (as mentioned in the Introduction section) have been identified along the western continental margin of India (Mattait et al. 1973; Nair et al. 1982a). Later studies by Rao and Rao (1995) and Kessarkar et al. (2003) have endorsed this view. While the Nd isotopic studies (Kessarkar et.al., 2003) were reasonably consistent with clay mineral distribution, Sr isotopic data of western continental margin was ambiguous with respect to source areas as $\mathrm{Sr}$ isotopes are very sensitive to weathering and laterization (Kessarkar et al. 2003).

Two different provinces of shelf sediments are also evident in the plot $\mathrm{Na}_{2} \mathrm{O}+\mathrm{K}_{2} \mathrm{O}$ versus $\mathrm{SiO}_{2}$ (Fig. 3). Shelf sediments from southern transects (south of Goa) fall in the acidic domain (high $\mathrm{SiO}_{2}$ content) while those from north of Goa fall in the basaltic/ basaltic andesite region. This figure shows that four samples (CAL, KANNUR and MNG coastal samples) from the southern sector fall in the basaltic region along with samples from northern transects (Fig. 3), which implies a Deccan Trap basaltic source, probably due to redistribution by coastal currents transporting the sediments from north. Relatively higher $\mathrm{K}_{2} \mathrm{O} / \mathrm{Na}_{2} \mathrm{O}$ ratios were observed for the northern transects with highest ratio (3.4) for the 
sediment off DWA (Table 3), which could be due to high mica (illite) content, characterized by Indus derived products (Nair et al. 1982a; Rao and Rao 1995).

Chondrite-normalized spidergrams encompassing 21 major, trace and rare-earth element data of sediments from 30m depth (chondrite values from Sun and McDonough 1989; elemental content on $c f b$ ) show distinct variation in magnitude with higher elemental content in sediments from north of Goa (Fig. 4). The source rock composition is further evaluated using a La-Th-Sc ternary plot (Fig. 5). These elements are good indicators of provenance as these are virtually insoluble and thus transported nearly quantitatively into terrigenous sediment (McLennan et al. 1990). In addition, these elements are not affected by grain-size fractionation (like Zr, Hf, Nb, and Sn; McLennan et al. 1990) and were widely used to determine provenance (Taylor and McLennan 1985; Wronkiewicz and Condie 1990; McLennan et al. 1990; Nath et al. 2000 etc.). Like the provinciality noticed for major elements, sediments south of Goa fall closer to the granite and those north of Goa plot away from granite. Such distinct discrimination seems to be mainly controlled by Th and Sc content. Average Th content in sediments north of Goa is much lower ( 6.7 ppm) than that seen in south of Goa ( 15.7 ppm), which is close to that of granite (15 ppm; Condie 1993), which is again consistent with source rock geology. Th/Sc ratios which provide a sensitive index of mafic vs. felsic composition (McLennan et al. 1990) show distinctly different ratios (Table 5) in sediments from north of Goa (avg. 0.37) and south (avg. 1.23). Sediments derived from young source terrains such as Deccan Traps have low $\mathrm{Th}$ and $\mathrm{Th} / \mathrm{Sc}$ ratios compared to the old and well differentiated upper crust (McLennan et al. 1990) like the granulitic terrain in south.

\section{Trace and REEs constrain further local sources.-}

\section{Dwaraka to Goa.-}

In general, flat shale normalized rare earth element $\left(\operatorname{REE}_{(\mathrm{SN})}\right)$ patterns with positive $\mathrm{Eu}_{\text {ano }}$ are seen in the northern transects (off DWA and POR) while HREE enrichment is more prominent in the sediments from VER to GOA. In the perspective of major element composition shown above and the previous literature, two sources viz., Indus and Deccan basalts are responsible for the elemental make up of the sediments in this sector (Dwaraka-Goa). Therefore, the SN patterns of our sediments are compared to the patterns of particulates from Indus River (Goldstein and Jacobsen 1988) and the Deccan basalts (Lightfoot et al. 1990) in Fig. 2. It is not a convention to normalize the igneous and metamorphic rock REE data with shale, but we have used for comparability. While the flat SN patterns of our sediments (off DWA and POR) are more similar to Indus derived particulates, we found higher total REE content (124-174 ppm on $c f b$ ) and relatively higher $\mathrm{Eu}_{\text {ano }}(1.4)$ than the Indus suspended sediments ( $\Sigma R E E=92$ $\left.\mathrm{ppm} ; \mathrm{Eu}_{\mathrm{ano}}=1.25\right)$. This requires an additional source which could probably be from Deccan basalts. Past works have shown that the influence of Indus derived sedimentation is confined mainly until the northern part of the Gulf of Kachchh (Nair et al. 1982a; Rao 1991). Ramaswamy et al. (2007) have reported the transport of previously deposited Indus sediments in the continental shelf into the Gulf of Kachch. But the sample at the southern mouth of Gulf of Kachchh was found to have signatures of 
Deccan basalts. HREE enriched profiles were seen in sediments off VER to GOA, similar to the SN patterns of Deccan basalts (Lightfoot et al. 1990, Fig. 2).

Rubidium and $\mathrm{Rb} / \mathrm{Ga}$ ratios were used earlier to determine the source and dispersal of suspended sediments in the Gulf of Kachchh (Staubwasser and Sirocko 2001; Ramaswamy et al. 2007) and the Central Indian Basin sediments (Nath et al. 2007). $\mathrm{Rb}$ is a typical dispersed element that is not associated with any specific Rb mineral (Wedepohl 1970), but is present in K-containing minerals, such as mica, K-feldspar, and clays (Horstman 1957). Rb concentrations were in general higher in the northern area compared to the central and southern parts of the western continental margin of India (Table 4, Fig. 1c). Rb concentration and $\mathrm{Rb} / \mathrm{Ga}$ ratios on $c f b$ showed higher values for the transect off DWA (98 ppm and 7 respectively), very similar to the sediments of Indus and Pakistan margins north of Gujarat (97.6 ppm and 5.87 respectively; Sirocko et al. 2000). Moderate Rb values (55 to 65 ppm) were seen in transects off MUM and VER, which is closely comparable to the Deccan Trap basalts (Chandrasekharam et al. 1999). Similar moderate values continue all along the coastal sediments until KANNUR in the southern area suggesting the influence of Deccan basalts (Table 4, Fig. 1c) in this region.

\section{Goa to Cape Comorin.-}

While the major element data $(\mathrm{Si}, \mathrm{Ti}$ and $\mathrm{Mg}$ ) broadly divide the entire study area into two distinct provinces, $\mathrm{REE}_{(\mathrm{SN})}$ patterns discern additional sources (Fig. 2). Sediments off MNG to CAL showed nearly flat SN pattern with moderate positive $\mathrm{Eu}_{\text {ano }}(1.3)$, the patterns more similar to those derived from Deccan basalts in the north (Fig. 2) probably suggesting the role of coastal currents in transporting sediments to the south. However, the sediments off KOLLAM and KOCHI show high LREE/HREE fractionation $\left(\mathrm{La}_{\mathrm{n}} / \mathrm{Yb}_{\mathrm{n}}=2-3.5\right)$ with steep sloping down pattern and high $\Sigma \mathrm{REE}$ concentrations (Fig. 2 and Table 5). The LREE enrichment and steep HREE pattern for the sediments is consistent with earlier studies from SW coast of India (Nath et al. 2000). Gneisses and charnockites in south India formed by retrograde metamorphism (Allen et al. 1985) showed similar pattern (Fig. 2) with positive $\mathrm{Eu}_{\text {ano }}$ on a shale normalization basis (Nath et al. 2000). While the positive $\mathrm{Eu}_{\text {ano }}$ (1.6) in coastal sediment off KOCHI (30m water depth) is possibly due to the presence of plagioclase feldspar (McLennan 1989), higher $\Sigma$ REE content in sediments from deeper depths is possibly related to the monazite bearing placers (REE bearing minerals), which are widespread in the southern Kerala coast. The coastal sample off TVM (stn.7) with high sand content and low $\mathrm{CaCO}_{3}$ has very low $\Sigma$ REE concentration. Earlier, Singh and Rajamani (2001a) showed that coarser sand fractions have lower REE abundance compared to finer silt and clay fractions in Kaveri flood plains. Sediment samples from the south west coast of India are dominated by sand fraction ( $>90 \%$ ), and yet the $\Sigma$ REE vary between 25 and $443 \mathrm{ppm}$ on $c f b$ (Table 5). It explains that within a given sediment grain size, mineralogy may control REE chemistry. SN patterns are different for southern samples, where the coastal sediment off CAPE COM (stn. 1) exhibited HREE depletion with negative $\mathrm{Eu}_{\text {ano }}$ typical of sediments derived from charnockites (Singh and Rajamani 2001a). Distinctly different patterns of the southernmost transect (which is at the tip of Indian peninsula) likely represent the influence of Bay of Bengal derived sediments. Chauhan and Gujar (1996) 
reported that the sediments from the SW coast of India can have the source characteristics of Bay of Bengal $(\mathrm{BoB})$ which are influenced by intrusion of particulates and waters from $\mathrm{BoB}$ during the north east monsoon.

While the earlier studies broadly identify basaltic source between Gujarat and Goa and gneissic source for south of Goa, this section demonstrates that the REE geochemistry identify additional local sources in the southwest coast of India and demonstrates the efficiency of sediment REEs in preserving the source characters (McLennan 1989; Taylor and McLennan 1985; Condie 1993; Nath et al. 2000).

\section{Signatures of variability in weathering intensity}

Chemical weathering alters the composition of siliciclastic sediments, where cations such as $\mathrm{Ba}, \mathrm{Cs}, \mathrm{Al}$ etc. remain fixed in the weathering residue in preference to smaller cations $(\mathrm{Na}, \mathrm{Ca}, \mathrm{Sr})$ which are selectively leached (Nesbitt et al. 1980; Fedo et al. 1996; Nath et al. 2000). These chemical changes are imprinted in the sedimentary record and provide a useful tool for monitoring source-area weathering conditions. From the geochemical data of fine grained sediments, chemical index of alteration (CIA) can be calculated based on the formula proposed by Nesbitt and Young (1982) using molecular proportions

$$
\mathrm{CIA}=\left[\mathrm{Al}_{2} \mathrm{O}_{3} /\left(\mathrm{Al}_{2} \mathrm{O}_{3}+\mathrm{CaO} *+\mathrm{Na}_{2} \mathrm{O}+\mathrm{K}_{2} \mathrm{O}\right)\right] \times 100
$$

where $\mathrm{CaO}^{*}$ and $\mathrm{Na}_{2} \mathrm{O}$ represent $\mathrm{Ca}$ and $\mathrm{Na}$ in the silicate fraction only. CIA values are reported on a general scale of 40-100 where it varied between 70-75 for average shales, below 50 for unweathered igneous rocks and close to 100 for residual clays with high kaolinite and gibbsite content (Nesbitt and Young 1982; Nath et al. 2000 and references therein). CIA monitors the progressive alteration of plagioclase and potassium feldspars to clay minerals. Earlier studies on a coastal sedimentary environment (riverine, estuarine and inner shelf) from the SW coast of India has shown very high CIA values in conjunction with LREE enrichment and major elements reflecting the signatures of intense chemical weathering in the area (Nath et al. 2000). In the upper reaches of the Cauvery catchment area in southern India, Sharma and Rajamani (2000) found that the Archean Peninsular Gneisses exhibit a greater degree of weathering in the field relative to the massive charnockites and granites. Their CIA values $(=50)$ suggest that the gneisses have suffered only incipient chemical weathering for the extent of physical weathering undergone by them. CIA values for the present study varied between 51 and 88 (Table 3) with higher values for the coastal samples off CAL, KANNUR, MNG and GOA (>85) indicating higher chemical weathering in their source terrains. In general, average CIA of sediments (considering all depths) north of Goa is 77 compared to those from south of Goa (70, Table 3). It has already been shown in the provenance section that the sediments north of Goa have a provenance in Deccan basalt regions. Considerable spatial variability in the intensity of chemical weathering of Deccan basalts was noticed by Das and Krishnaswami (2007). They have reported CIA values for the sediments in the rivers flowing through Deccan Trap regions to range between 42 and 92, compared to $\sim 37$ for the

Deccan basalts. While the lower CIA values were attributed to $\mathrm{CaCO}_{3}$ (semi-arid climate facilitating $\mathrm{CaCO}_{3}$ precipitation and restricting chemical weathering/erosion), higher CIA values are generally associated with sediments from basins with higher runoff (Das and Krishnaswami 2007). Consistent 
with their different provenance, sediments off TVM show lower CIA values (Table 3; Fig. 6a). Similar low degree of chemical weathering is reported from the floodplain sediments of river Kaveri (Singh and Rajamani 2001a, b) in the east coast of India.

The upper continental crust (UCC) consists of $41 \%$ by volume of plagioclase (Wedepohl 1969). Plagioclase is easily mobilized even at mild weathering conditions when compared to potassium feldspar (Martin and Meybeck 1979; Canfield 1997; Selvaraj and Chen 2006 and references therein). Therefore, monitoring the plagioclase weathering provides additional information for silicate weathering of sediments and sedimentary rocks. Plagioclase Index of Alteration (PIA) can be evaluated following Fedo et al. (1995) using molecular proportion

$$
\mathrm{PIA}=\left[\left(\mathrm{Al}_{2} \mathrm{O}_{3}-\mathrm{K}_{2} \mathrm{O}\right) /\left(\mathrm{Al}_{2} \mathrm{O}_{3}+\mathrm{CaO}^{*}+\mathrm{Na}_{2} \mathrm{O}-\mathrm{K}_{2} \mathrm{O}\right)\right] \times 100
$$

where $\mathrm{CaO}^{*}$ and $\mathrm{Na}_{2} \mathrm{O}$ represent $\mathrm{Ca}$ and $\mathrm{Na}$ in the silicate fraction only. The index gives values of 50 for fresh rocks and values close to 100 for clay minerals such as kaolinite, illite, and gibbsite (Fedo et al. 1995; 1996). Consistent with CIA data, PIA values for our samples varied between 52 and 94 with higher values for the coastal samples off CAL, KANNUR, MNG and GOA (>90) (Fig. 6). This indicates that most of the plagioclase has been converted to secondary clay minerals for these sediments. Some kaolinite together with gibbsite must have been derived from the Western Ghats located on the GoaCochin coast which also receives maximum rainfall during southwest monsoon (Rao and Rao 1995). Coastal sediments off RAT and MUM also showed higher values of PIA (88-89, Table 3).

Degree of weathering is also evaluated with the discrimination ternary plots of $\mathrm{Al}_{2} \mathrm{O}_{3}-\left(\mathrm{CaO}+\mathrm{Na}_{2} \mathrm{O}\right)-$ $\mathrm{K}_{2} \mathrm{O}$ (A-CN-K in molecular proportions; Fig. 7a), which refers to the CIA values and $\left(\mathrm{Al}_{2} \mathrm{O}_{3}-\mathrm{K}_{2} \mathrm{O}\right)-$ $\mathrm{CaO}-\mathrm{Na}_{2} \mathrm{O}$ (A-C-N) (Fig. 7b) depicting PIA values. CIA values of our sediments vary between 51 and 88 and fall on a trend parallel to the $\mathrm{A}-\mathrm{C}+\mathrm{N}$ join, while three samples from south of Goa (coastal samples of CAL, KANNUR and MNG) and four samples from north of Goa (coastal samples from GOA, RAT and MUM) fall close to the $\mathrm{Al}_{2} \mathrm{O}_{3}$ axis (apex indicating kaolinite, chlorite and gibbsite) showed that these samples had undergone intense chemical weathering. Similarly, these sediments also fall close to the $\mathrm{Al}_{2} \mathrm{O}_{3}-\mathrm{K}_{2} \mathrm{O}$ apex in the PIA ternary plot (Fig. 7b). Both these plots, and also the CIA and PIA values supported intense weathering for these sediments, indicating their highly aluminous character. Sediments from south west coast of Kerala (off TVM, KOLLAM and KOCHI) showed low PIA values indicate the presence of less weathered plagioclase feldspars in these sediments.

Variability in degree of chemical weathering is seen with the change in provenance. In general, the sediments north of Goa predominantly derived from Deccan basalts show higher chemical weathering index. Chemical weathering in Deccan traps of India (a basaltic province) is recently studied based on major ions in Narmada, Tapti Rivers and Godavari tributaries (Dessert et al. 2001) and in Krishna river system which flow through Deccan traps and drain into the Arabian Sea (Ramesh and Subramanian 1988 and Das et al. 2005). These studies showed that basaltic provinces weather to a greater extent compared to granites and gneisses (Dessert et al. 2003; Das et al. 2005 and references therein). 
While the chemical weathering intensity varies between the northern and southern parts of the western continental shelf of India, overall the values of weathering indices suggest only a moderate chemical weathering despite the intense orographic rainfall in the area.

\section{$C$ and $N$ content and their isotopic signatures: Has Provenance any control on the nature of organic matter?}

$\mathrm{C}_{\text {org }}$ and $\mathrm{N}(\%), \delta^{13} \mathrm{C}$ and $\delta^{15} \mathrm{~N}(\%)$ values of sediments are shown in Table 6. $\mathrm{C}_{\text {org }}$ showed wide spatial variation from 0.13 to $3.5 \%$ from south to north. Generally, it is higher in coastal sediments (30m) in the transects off CAL to Goa ( $>3 \%$, Table 6). The organic carbon at this depth must be from land run-off, less likely from planktonic material from the overlying water. In contrast, sediments from $100 \mathrm{~m}$ depth were low in $\mathrm{C}_{\text {org }}$ content (Table 6). The surficial carbonate sediments on the outer shelf are of relict nature and are of older age (Stewart et al. 1965; Nair and Pylee 1968; Rao and Wagle 1997). These areas preclude significant terrigenous sediment accumulation either because of long shore currents which carry terrestrial sediments along the coast or because of bypassing of sediments in the shelf regions (Nair et al. 1982b). Hence, these sediments are exposed for longer time to ambient $\mathrm{O}_{2}$ than the sediments on either side of this relict sediment band. Long oxygen exposure time could be a determinant of low organic carbon preservation (e.g. Burdige 2007) in these sediments.

The average organic carbon content for $200 \mathrm{~m}$ samples is $1.5 \%$ (Table 6 ) where overlying water showed suboxic values with $<0.1 \mathrm{ml} / \mathrm{L}$ of dissolved oxygen (Table 1). As reported earlier, several factors such as dissolved oxygen content of bottom waters, productivity of water column, sedimentation rates etc. control the preservation of organic matter (e.g. Calvert et al. 1995; Prakash Babu et al. 1999; Rao and Veerayya 2000; Cowie et al. 1999; 2009). As the mass accumulation rates gives a better information than the concentration, burial fluxes of $\mathrm{C}_{\text {org }}$ were calculated using dry bulk density (derived from

$\mathrm{CaCO}_{3}$; Snoeckx and Rea 1994) and ${ }^{210} \mathrm{~Pb}_{\text {excess }}$ based sedimentation rates from literature (Borole, 2008), which are close to our sampling locations. Sedimentation rates are only available for the transects north of Mangalore (off MNG, GOA, RAT, MUM; compilation by Borole, 2008) and the calculations indicate higher $\mathrm{C}_{\text {org }}$ burial fluxes for the samples north of Goa (MNG 30m- 0.04; GOA 30m- 0.11, MUM 30m0.27 ; and POR $100 \mathrm{~m}-0.53,200 \mathrm{~m}-0.33$, and DWA $200 \mathrm{~m}-0.58 \mathrm{~g} / \mathrm{cm}^{2} / \mathrm{yr}$ ) possibly because of higher productivity in the northern area. While the seasonal climatic variability controls the regional productivity variation in the Arabian Sea, the southeastern Arabian Sea remains oligotrophic during a major part of the year, but the northeastern Arabian Sea has fairly high phytoplankton stock during most part of the year (Jyothibabu et al. 2010 and references therein) which explain higher burial fluxes in the northern region.

$\mathrm{N} \%$ also showed similar variation like $\mathrm{C}_{\text {org }}$ with minimum value for the samples having low $\mathrm{C}_{\text {org }}$ content and vice versa with $\mathrm{r}^{2}=0.974$. $\mathrm{C} / \mathrm{N}$ molar ratio varied between 6.9 and 14 , with most of the values falling between 10 and 12 (Table 6), closer to the reported range of marine sedimentary organic matter in the northeastern Arabian Sea (8+2; Reichart 1997; Bhushan et al. 2001). Certain transects (KOCHI, 
KANNUR, MNG etc.) showed decreasing trend of $\mathrm{C} / \mathrm{N}$ ratios towards offshore, which indicates less terrestrial influence at deeper stations.

In addition to $\mathrm{C} / \mathrm{N}$ ratio, $\delta^{13} \mathrm{C}$ is commonly used as an indicator of terrestrial organic matter to the oceans (Peters et al. 1978). The $\delta^{13} \mathrm{C}$ values vary between -18.2 and $-21.6 \%$ with higher values for northern transects off POR and DWA (Table 6). Most of the values are closer to the marine organic matter value of $-20 \%$, though they are from coastal $(30 \mathrm{~m})$ or offshore $(200 \mathrm{~m})$ stations. Fontugne and Duplessy (1986) reported $-26 \%$ for riverine particulate organic matter and $-20 \%$ for marine source. We have compiled the earlier literature values of $\delta^{13} \mathrm{C}$ in sediments from the Arabian Sea (from Fontugne and Duplessy 1986; Agnihotri et al. 2003, Mazumdar et al. 2009 and Cowie et al. 2009) and plotted along with our data in Fig. 8a. It is evident from the plot that all samples showed marine signatures for the shelf and deep sea sediments, except that our samples from the northern transects showed higher values (-18.2 to $-19 \%$ ). Higher values coincide with the change in provenance (off Gujarat - Indus and Deccan basalt derived) suggest a role of vegetation and soil type on carbon isotopic composition.

Carbon isotopic ratios are consistent with the earlier findings that sedimentary organic matter accumulating in deltas and open continental margins (which together account for more than $90 \%$ of all marine organic carbon burial; Berner 1989) is predominantly marine derived (Gearing et al. 1977; Hedges and Mann 1979; Gough et al. 1993). Schlünz and Schneider (2000) have estimated that only about $10 \%$ of the $\mathrm{C}_{\mathrm{org}}$ discharged from rivers is finally buried in the sediments of the Amazon continental shelf in modern times. Inorganic geochemical tracers $\mathrm{Al}$ and $\mathrm{Ti}$ content are higher in most of the coastal stations compared to offshore ones suggesting the higher terrestrial influence. However, this contrasts with the predominantly marine signature of organic matter even in the shallow shelf stations ( $30 \mathrm{~m}$ depth). Similar high $\delta^{13} \mathrm{C}$ values (marine signature) are also reported in a shallow sediment core off Goa, India (-21\%, Agnihotri et al. 2008) at a water depth of $45 \mathrm{~m}$. But, isotopic data from Mandovi estuary which can potentially supply to the sediments offshore Goa showed significant terrestrial influence $(-26 \%)$ for the suspended particulate organic matter close to the estuarine end (Maya et al. 2010). Similarly, isotopic studies carried out on the coastal sediments of Kerala (SW coast of India), showed $\sim-23 \%$ for the sediments from shallow depths $(5 \mathrm{~m})$ and $\sim-21 \%$ from $40 \mathrm{~m}$ depths (unpublished data). Thus one possibility is rapid oxidation of terrestrial organic carbon entering the marine environment (e.g., Schlünz and Schneider 2000). Lack of significant terrestrial organic matter in the Arabian Sea is different from that observed in Bay of Bengal (Galy et al. 2007) and Ayeyarwady continental shelf (Andaman Sea; Ramaswamy et al. 2008), where shelf sediments and even deep sea sediments showed terrestrial $\delta^{13} \mathrm{C}$ signatures.

As $\mathrm{C} / \mathrm{N}$ ratio is also an indicator for the sources of organic matter (Meyers, 1997), we have plotted $\delta^{13} \mathrm{C}$ versus $\mathrm{C} / \mathrm{N}_{\text {molar }}$ ratio of the sediments studied here (Fig. 9); which showed a correlation coefficient of $\mathrm{r}=0.48(\mathrm{n}=37)$. A significant negative correlation between $\delta^{13} \mathrm{C}$ and $\mathrm{C} / \mathrm{N}$ ratios is expected if both of these variables are indicating the source (i.e., organic matter with high $\mathrm{C} / \mathrm{N}$ ratio should have much lighter $\delta^{13} \mathrm{C}$ value, Wu et al. 2002). However, no pronounced relation is seen between $\delta^{13} \mathrm{C}$ and $\mathrm{C} / \mathrm{N}$ ratios. At a given $\mathrm{C} / \mathrm{N}$ ratio, considerable spread of $\delta^{13} \mathrm{C}$ is seen (Fig. 9). In view of lack of significant 
correlation between these two parameters, $\delta^{13} \mathrm{C}$ was preferred for source characterization (e.g. Ramaswamy et al. 2008, Gao et al. 2012 etc.). However, a significant point to be noticed in this plot (Fig. 9) is clear demarcation in $\delta^{13} \mathrm{C}$ values between the coastal sediments (30 and 50m water depth) in north and south of Goa. All the sediments (except one) from south of Goa show lighter (than -20.5) $\delta^{13} \mathrm{C}$ values and a provinciality similar to the major element composition is evident. It is also possible that heavier $\delta^{13} \mathrm{C}$ values in the north ( -19\%o) could have more contribution from $\mathrm{C} 4$ plants. Incidentally, similar heavier $\delta^{13} \mathrm{C}$ values are also found in terrestrial plants in Deccan basalt dominated areas north of Goa (Bowen and West, 2008) suggesting a role of provenance (in a logical sequence of parent rock controlling soil type which in turn determines the type of vegetation) on the $\delta^{13} \mathrm{C}$ variability.

$\delta^{15} \mathrm{~N}$ of sedimentary organic matter depositing in modern sediments overlain by the OMZ can serve as proxy for past changes in variation in water-column denitrification (Schafer and Ittekkot 1993; Altabet et al. 1995). Additional processes which could alter nitrogen isotopic ratios are nitrogen fixation (Altabet 2006; Maya et al. 2011) and diagenetic changes (Chen et al. 2008).

$\delta^{15} \mathrm{~N}$ values of present samples varied between 4.6 and 9.1\% (Table 6) with values for most of the samples falling between 5 and 7\%o. These values are higher than the $\delta^{15} \mathrm{~N}$ values of terrestrial organic matter ( $4 \%$, Kao and Liu 2000). If organic matter in the surface sediment is a mixture of terrigenous and marine sources, then positive correlation between $\delta^{15} \mathrm{~N}$ and $\delta^{13} \mathrm{C}$ is expected, but in our study only a weak correlation $(r=0.19, n=37)$ was observed suggesting that the $\delta^{15} \mathrm{~N}$ variation is not due to mixing of terrestrial and marine organic matter. Thus, the observed higher $\delta^{15} \mathrm{~N}$ values are probably due to denitrification signatures in the overlying water column (Peters et al. 1978; Brandes et al. 1998; Agnihotri et al. 2003). Early diagenetic degradation of organic matter would increase $\delta^{15} \mathrm{~N}$ values, resulting in negative relation with $\mathrm{C}_{\text {org }}$ and $\mathrm{N} \%$. But lack of a significant relationship in the present study $\left(\mathrm{r}=0.27 ; \mathrm{n}=37\right.$ for $\delta^{15} \mathrm{~N}$ vs. $\mathrm{N} \%$ ) indicates that the diagenesis may not have altered the isotopic signature significantly (Altabet et al. 1999; Agnihotri et al. 2003). Comparatively higher $\delta^{15} \mathrm{~N}$ values $(>7 \%$ ) are observed for the northern transects (north of Ratnagiri, Fig. 8b) which is possibly due to a ${ }^{14} \mathrm{~N}$ depleted nitrate pool caused by denitrification within the OMZ (Ganeshram et al. 1995; Agnihotri et al. 2003; Cowie et al. 2009). Naqvi (1987; 1991) and Somasundar and Naqvi (1988) have reported the region between $15^{\circ}$ and $21^{\circ} \mathrm{N}$ as the area of intense denitrification and the southern boundary of denitrification oscillate between latitudes 12 and $14^{\circ} \mathrm{N}$ in the eastern and central Arabian Sea. Earlier studies also showed that the regions of high biological productivity (such as Somalia coast and north western Arabian Sea) are geographically well separated from the intense denitrifying area (Naqvi 1991; 1994). Similar N-S variations in $\delta^{15} \mathrm{~N}$ values (8-9\% in north and 6-7\%o in the south) of sinking particles and surface sediments from the northern Indian Ocean were found by Gaye-Haake et al. (2005). Agnihotri et al. (2003) also reported enriched $\delta^{15} \mathrm{~N}$ values for the sediments from the northern Arabian Sea (off MUM, 9.4\%o) compared to southern transects. Hence, the nitrogen isotopic ratios of our surficial sediments on a regional scale are responding to varying denitrification conditions and thus this data may have application for interpreting such events from the sedimentary records. 


\section{CONCLUSIONS}

A distinct north-south provinciality in terms of elemental variability is seen for the western continental margin sediments. The Si- poor and Ti-Mg- rich sediments in northern part (off Dwaraka to Goa) juxtapose with Deccan Trap basaltic terrain on land. On the other hand, sediments in south from Goa to Cape Comorin are Si-rich and Ti-Mg-poor and have granulitic terrain as the source area. However, REE content, their fractionation indices and shale-normalized patterns demonstrate additional local sources in the southwest coast of India.

Weathering Indices such as CIA, PIA and discrimination plots involving oxides of $\mathrm{Al}, \mathrm{Ca}, \mathrm{Na}$ and $\mathrm{K}$ also showed variability in the intensity of weathering with respect to the sediment provenance. In general, the sediments north of Goa having a provenance of Deccan basalts show higher chemical weathering index compared to those from south of Goa suggesting that the basaltic provinces weather to a greater extent compared to granites and gneisses. While the provenance control on the degree of alteration was visible, the values of weathering indices suggest only a moderate chemical weathering despite the intense orographic rainfall in the area.

Molar $\mathrm{C} / \mathrm{N}$ ratios and higher $\delta^{13} \mathrm{C}$ values of organic matter in all sediments including those from shallow shelf $(30 \mathrm{~m})$ stations show values closer to marine sedimentary organic matter. $\delta^{13} \mathrm{C}$ values and their relation with $\mathrm{C} / \mathrm{N}$ ratios show a north-south provinciality similar to the inorganic geochemical tracers of provenance. In the sediments sourced from Deccan Traps in the north, heavier isotopic values were present implying a relatively higher contribution from C-4 type vegetation, consistent with heavier $\delta^{13} \mathrm{C}$ values in terrestrial plants in source regions. Comparatively heavier $\delta^{15} \mathrm{~N}$ values $(>7 \%)$ are observed for the northern transects (north of Ratnagiri) and are attributed to a ${ }^{14} \mathrm{~N}$ depleted nitrate pool caused by intense denitrification within the OMZ.

\section{ACKNOWLEDGEMENTS}

We thank Director, NIO for permission to use the facilities and S.K. thanks former Director Dr. E. Desa for his support and Prof. R. Damodaran, former Dean of CUSAT, Kerala for sharing the samples. The sampling was carried out under MR-LR benthic programme funded by MoES, Government of India and help extended by Dr. Joydas for sample collection is acknowledged. Analytical support received from Ms. Naman and Dr. T.G. Rao (NGRI, Hyderabad) for ICP-MS analysis is greatly acknowledged. S.K. thanks Dr. S.W.A. Naqvi for permission to use IRMS facility and technical assistance extended by Ms. S. Karapurkar is greatly appreciated. We also acknowledge Dr.A. Mudholkar and Mr.C. Moraes for XRF analysis. Dr. P.Kessarkar, Vineesh, Brenda and Uchil are thanked for their help in drawing some of the figures and Dr. R.Agnihotri for his constructive comments. Dr. Richard Murray, anonymous reviewer and AE Dr. Rajiv Sinha are thanked for their painstaking reviews. This is NIO contribution no: 


\section{REFERENCES}

Agnihotri, R., Bhattacharya, S.K., Sarin, M.M., And Somayajulu, B.L.K., 2003, Changes in surface productivity, sub-surface denitrification and SW monsoon during the Holocene: a multi proxy record from the eastern Arabian Sea: The Holocene, v. 13, p. 701-713.

Agnihotri, R., Kurian, S., Fernandes, M., Reshma, K., Souza, W. D'., And Naqvi, S.W.A., 2008, Variability of subsurface denitrification and surface productivity in the coastal eastern Arabian Sea over the past seven centuries: The Holocene, v. 18, p. 755-764.

Allen, P., Condie, K.C., AND NARAYAnA, B.L., 1985, The geochemistry of prograde and retrograde charnockite-gneiss reactions in southern India: Geochimica et Cosmochimica Acta, v. 49, p. 323336 .

Altabet, M. A., 2006, Isotopic tracers of the marine nitrogen cycle, In: Marine organic matter: Chemical and biological markers, edited by: Volkman, J., The handbook of environmental chemistry, Springer-Verlag, p. 251-293.

Altabet, M. A., Francois, R., Murray, D. W., And Prell, W. L.1995, Climate related variations in denitrification in the Arabian Sea from sediment 15N/14N ratios: Nature, v. 373, p. 506-509.

Altabet, M.A., MurRay, D.W. AND Prell, W.L. 1999, Climatically linked oscillations in Arabian Sea denitrification over the past 1 m.y.: implications for the marine N cycle: Paleoceanography v. 14, p. $732-743$.

Balaram, V., AND RaO, T.G., 2002, Rapid multi-element determination in geological samples by microwave acid digestion and ICP-MS: Proceedings $3^{\text {rd }}$ ISMAS (BC) Bangalore (2002), p. 22-27.

BERNER, R.A., 1989, Biogeochemical cycles of carbon and sulfur and their effect on atmospheric oxygen over Phanerozoic time: Palaeogeography, Palaeoclimatology, Palaeoecology, v. 75, p. 97122.

Bhushan, R., DutTA, K., AND Somayajulu, B.L.K., 2001, Concentrations and burial fluxes of organic and inorganic carbon on the eastern margins of the Arabian Sea: Marine Geology, v. 178, p. 95113.

Borole, D.V., 2008, Sediment transport and dispersal studies using radio isotopic tracers in the coastal environments of India: Proceedings of the international symposium on sediment management, July 2008, Lille, France, p.129-142.

Bowen, G.J AND West, J.B., 2008, Isotope Landscapes for Terrestrial Migration Research: Terrestrial Ecology, v.2, p. 79-105.

Brandes, J.A., Devol, A.H., Yoshinari, T., Jayakumar, D.A., AND NaQvi, S.W.A., 1998, Isotopic composition of nitrate in the central Arabian Sea and eastern tropical North Pacific: a tracer for mixing and nitrogen cycles: Limnological Oceanography, v. 43, 1680-1689.

BuRdige, D.J., 2007, Preservation of Organic Matter in Marine Sediments: Controls, Mechanisms and an Imbalance in Sediment Organic Carbon Budgets?: Chemical Reviews, v. 107, p. 467-485. 
Calvert, S.E., Pederson, T.F., Naidu, P.D., and Von Stackelberg, U., 1995, On the organic carbon maximum on the continental slope of the eastern Arabian Sea: Journal of Marine Research, v. 53, p.269-296.

CANFIELD, D.E., 1997, The geochemistry of river particulates from the continental USA: Major elements: Geochimica et Cosmochimica Acta, v. 6, p. 3349-3365.

Chandrasekharam, D., Mahoney, J.J., Sheth, H.C., and Duncan, R.A., 1999, Elemental and Nd$\mathrm{Sr}-\mathrm{Pb}$ isotope geochemistry of flows and dykes from the Tapi rift, Deccan flood basalt province, India: Journal of Volcanology and Geothermal Research, v. 93, p. 111-123.

Chauhan, O.S., AND Gujar, A.R., 1996, Surficial clay mineral distribution on the southwestern continental margin of India: Evidence of input from the Bay of Bengal: Continental Shelf Research, v. 16, p.321-333.

Chen, F., Zhang, L., Yang, Y., And Zhang, D., 2008, Chemical and isotopic alteration of organic matter during early diagenesis: Evidence from the coastal area off-shore the Pearl River estuary, south China: Journal of Marine Systems, v. 74, p. 372-380.

CondiE, K.C., 1993, Chemical composition and evolution of the upper continental crust: contrasting results from surface samples and shales: Chemical Geology, v. 104, p. 1-37.

CowIE, G., 2005, The biogeochemistry of Arabian Sea surficial sediments: A review of recent studies: Progress in Oceanography, v. 65, p. 260-289.

Cowie, G.L., Calvert, S.E., Pedersen, T.F., Schulz, H., And Von Rad, U., 1999, Organic content and preservational controls in surficial shelf and slope sediments from the Arabian Sea (Pakistan margin): Marine Geology, v. 161, p. 23-38.

Cowie, G.L., Mowbray, S., Lewis, M., Matheson, H., And McKenzie, R., 2009, Carbon and nitrogen elemental and stable isotopic compositions of surficial sediments from the Pakistan margin of the Arabian Sea: Deep Sea Research, II. v. 56, p. 271-282.

DAS, A., AND KRISHNASWAMY, S., 2007, Elemental geochemistry of river sediments from the Deccan Traps, India: Implications to sources of elements and their mobility during basalt -water interaction: Chemical Geology, v. 242, p. 232-254.

Das, A., Krishnaswami, S., SARIN, M.M., AND PAnde, K., 2005, Chemical weathering in the Krishna Basin and Western Ghats of the Deccan Traps, India: Rates of basalt weathering and their controls: Geochimica et Cosmochimica Acta, v. 69, p. 2067-2084.

Dessert, C., Dupre, B., Francois, L. M., Schott, J., Gaillardet, J., Chakrapani, G., And Bajpai, S., 2001, Erosion of Deccan Traps determined by river geochemistry: impact on the global climate and the ${ }^{87} \mathrm{Sr} /{ }^{86} \mathrm{Sr}$ ratio of sea water: Earth and Planetary Science Letters, v. 188, p. 459-474.

Dessert, C., Dupre, B., Gaillardet, J., Francois, L. M., And Allegre, C. J., 2003, Basalt weathering laws and the impact of basalt weathering on the global carbon cycle: Chemical Geology, v. 20, p. $1-17$. 
DuCKLOW, H.W., AND MCCAllister, S.L., 2004, The biogeochemistry of carbon dioxide in the coastal oceans. In: Robinson, A., Brink, K. (Eds.), The Sea, v. 13. Harvard University Press, p. 269-315.

Fedo, C.M., Nesbitt, H.W., AND Young, G.M., 1995, Unraveling the effects of potassium metasomatism in sedimentary rocks and paleosols, with implications for paleoweathering conditions and provenance: Geology, v. 23, p. 921-924.

Fedo, C.M., Eriksson, K.A., AND Krogstad, E.J., 1996, Geochemistry of shales from the Archean $(\sim 3.0 \mathrm{Ga})$ Buhwa Greenstone Belt, Zimbabwe: implications for provenance and source-area weathering: Geochimica et Cosmochimica Acta, v. 60, p. 1751-1763.

Fontugne, M.R., AND DuPlessy, J.C., 1986, Variations of the monsoon regime during the upper Quaternary: evidence from carbon isotopic record of organic matter in north Indian Ocean sediment cores: Palaeogeography, Paleoclimatology, Palaeoecology, v. 56, p. 69-88.

Galy, V., France-Lanord, C., Beyssac, O., Faure, P., Kudrass, H., and Palhol, F., 2007, Efficient organic carbon burial in the Bengal fan sustained by the Himalayan erosional system: Nature, 450, doi: $10.1038 /$ nature 06273 .

Ganeshram, R.S., Pedersen, T.F., Calvert, S.E., AND Murray, J.M., 1995, Large changes in oceanic inventories from glacial to interglacial periods: Nature, v. 376, p. 755-758.

GAO, X., YANG, Y., AND WANG, C., 2012, Geochemistry of organic carbon and nitrogen in surface sediments of coastal Bohai Bay inferred from their ratios and stable isotopic signatures: Marine Pollution Bulletin, v. 64, p.1148-1155.

Gaye-HaAke, Lahajnar, B.N., Emeis, K.-Ch., Unger, D., RiXen, T., Suthhof, A., Ramaswamy, V., Schulz, H., PAROPKARI, A.L., GuPtha, M.V.S., AND ITTEKKOT, V., 2005, Stable nitrogen isotopic ratios of sinking particles and sediments from the northern Indian Ocean: Marine Chemistry, v. 96, p. 243-255.

Gearing, P., Plucker, F. E., AND Parker, P. L., 1977, Organic carbon stable isotope ratios of continental margin sediments, Marine Chemistry, v. 5, p. 251-266.

Goldstein, S. J., AND Jacobson, S. B., 1988, Rare earth elements in river waters: Earth and Planeteray Science Letters, v. 89, p. 35- 47.

Gough, M.A., Fauzi, R., Mantoura, C., And Preston, M., 1993, Terrestrial plant biopolymers in marine sediments: Geochimica et Cosmochimica Acta, v. 57, p. 945-964.

GOVINDARAJU, K., 1994, 1994 compilation of working values and sample description for 383 geostandards: Geostandard Newsletter, v. 18 (Special Issue), p.158.

Grasshoff, K., Ehrhardt, M., And Kremling, K., 1983, Methods of Seawater Analysis: Verlag Chemie, p. 419.

HASHIMI, N.H., AND NAIR, R.R, 1986, Climatic aridity over India 11,000 years ago: Evidence from feldspar distribution in shelf sediments: Palaeogeography, Palaeoclimatology, Palaeoecology, v. 53, p. 309-319. 
Hashimi, N.H., NaIR, R.R., KidwaI, R.M., AND RAO, V.P., 1982, Carbonate mineralogy and faunal relationship in tropical shallow water marine sediments: Sedimentary Geology, v. 32, p. 89-96.

Hedges, J.I., AND MANN, D. C., 1979, The lignin geochemists of marine sediments from the Southern Washington coast: Geochimica et Cosmochimica Acta, v. 43, p. 1809- 1818.

Hedges, J.I., KeIL, R.G., And BenneR, R., 1997, What happens to terrestrial organic matter in the ocean?: Organic Geochemistry, v. 27, p. 195-212.

Higginson, M. J., AND Altabet, M.A., 2004, Comment on "Sedimentary phosphorus record from the Oman margin: New evidence of high productivity during glacial periods' by Tamburini, et al. Paleoceanography 19, PA2024 doi:10.1029/2004PA001017.

Horstman, E.L., 1957, The distribution of lithium, rubidium, and caesium in igneous and sedimentary rocks: Geochimica et Cosmochimica Acta, v. 12, p. 1-28.

Jyothibabu, R., Madhu, N.V., Habeebrehman, H., Jayalakshmy, K.V., Nair, K.K.C., AND ACHUTHANKUTTY, C.T., 2010, Re-evaluation of 'paradox of mesozooplankton' in the eastern Arabian Sea based on ship and satellite observations: Journal of Marine Systems, v. 81, p. 235251.

KAO, S.J., AND LIU, K.K., 2000, Stable carbon and nitrogen isotope systematic in human disturbed watershed (Lanyang-His) in Taiwan and the estimation of biogenic particulate organic carbon and nitrogen fluxes: Global Biogeochemical Cycles, v. 14, p. 189-198.

KaO, S.-J., ShiAH, F-K., WANG, C-H., AND LiU, K-K., 2006, Efficient trapping of organic carbon in sediments on the continental margin with high fluvial sediment input off southwestern Taiwan: Continental Shelf Research, v. 26, p. 2520-2537.

Kessarkar, P.M., RaO, V.P., Ahmed, S.M., And Anil Babu, G., 2003, Clay minerals and Sr-Nd isotope of the sediments along the western margin of India and their implications for sediment provenance: Marine Geology, v. 202, p. 55-69.

Le Maitre, R.W., Bateman, P., Dudek, A, Keller, J., Lameyre le Bas M.J., Sabine P.A., Schmid R., Sorensen H., Streckeisen A, Woley A.R And Zanettin B., 1989, A Classification of Igneous rocks and Glossary of Terms: Blackwell Scientific Publications, Oxford.

Legeleux, F., Reyss, J. I., Bonte, P., And Organo, C., 1994, Concomitant enrichments of V, Mo, As in suboxic continental margin sediments: Oceanologica Acta, v. 17, p. 417-430.

Lightfoot, P. C., Hawkesworth, C. J., Devey, C. W., Rogers N. W., and Van Calsteren, P. W. C., 1990, Source and Differentiation of Deccan Trap Lavas: Implications of Geochemical and Mineral Chemical Variations: Journal of Petrology, v. 31, p. 1165-1200.

Madhupratap, M., Prasannakumar, S., Bhattathiri, P.M.A., DileEPKumar, M., RaghuKumar, S., NAIR, K.K.C., AND RAMAIAH, N., 1996, Mechanism of the biological response to winter cooling in the northeastern Arabian Sea: Nature, v. 384, p. 549-552.

Marchig, V., 1972, Contributions to the geochemistry of recent sediments from the Indian Ocean: "Meteor" Forschungsergeb., Reihe C, No. 11, p. 1-104. 
Martin, J.-M., AND MeybecK, M., 1979, Elemental mass balance of material carried by major world rivers: Marine Chemistry, v. 7, p. 173-206.

Mascarenhas-Pereira, M.B.L., AND NATH, B.N., 2010, Selective leaching studies of sediments from a seamount flank in the Central Indian Basin: Resolving hydrothermal, volcanogenic and terrigenous sources using major, trace and rare-earth elements: Marine Chemistry, doi:10.1016/j. marchem.2010.03.004.

Mattait, B., Peters, J., AND EcKhardt, F.J., 1973, Results of petrographic analysis on sediments from the Indian Pakistan continental margin (Arabian Sea) (German), "Meteor" Forsch Ergebrisse Reiche no. 14, Suite 1-50.

Maya, M.V., Soares, M.A., Agnihotri, R., Pratihary., A.K., Karapurkar, S., Naik, H., And NAQVI, S.W. A., 2010, Variations in some environmental characteristics including C and N stable isotopic composition of suspended organic matter in the Mandovi estuary: Environmental and Monitoring Assessment, DOI 10.1007/s10661-010-1547-8.

Maya, M. V., Karapurkar, S. G., Naik, H., Roy, R., Shenoy, D. M., and Naqvi, S. W. A., 2011, Intra-annual variability of carbon and nitrogen stable isotopes in suspended organic matter in waters of the western continental shelf of India: Biogeosciences, v. 8, p. 3441-3456

Mazumdar, A., Peketi, A., Dewangan, P., Badesab, F., Ramprasad, T., Ramana, M.V., Patil, D.J., AND DAYA, A., 2009, Shallow gas charged sediments off the Indian west coast: Genesis and distribution: Marine Geology, v. 267, p. 71-85.

MCLENNAN, S.M., 1989, REE in sedimentary rocks: influence of provenance and sedimentary processes: Reviews in Mineralogy, v. 21, p. 170-199.

McLennan, S.M., TAYlor, S.R, MCCulloch, M.T., AND MAYnARD, J.B., 1990, Geochemical and Nd$\mathrm{Sr}$ isotopic composition of deep-sea turbidites: Crustal evolution and plate tectonic associations: Geochimica et Cosmochimica Acta, v. 54, p. 2015-2050.

MEYERS, P.A., 1997, Organic geochemical proxies of paleoceanographic, paleolimnologic, and paleoclimatic processes: Organic Geochemistry, v. 27, p. 213-250.

Milliman, J.D., AND MEADE, R.H., 1983, World-wide delivery of river sediment to the oceans: Journal of Geology, v. 91, p. 1-21.

Milliman, J.D., AND SYVITSKI, J.P.M., 1992, Geomorphic/tectonic control of sediment discharge to the ocean: the importance of small mountainous rivers: Journal of Geology, v. 100, p. 525-544.

Morey, G.B., AND SetTerholm, D.R., 1997, Rare earth elements in weathering profiles and sediments of Minnesota: Implications for provenance studies: Journal of Sedimentary Research, v. 67, p. 105115 .

MÜLler, G., AND GASTNER, M., 1971, “The Karbonat-Bombe”, a simple device for the determination of carbonate content in sediments, soils and other material: Neues Jahrbuch Minearalogie, v. 10, p. 466-469. 
Murty, P.S.N., RAO, Ch.M., AND RedDy, C.V.G., 1970, Distribution of Nickel in the marine sediments off the west coast of India: Current Science, v. 2, p. 30-32.

Murty, P.S.N., RaO, CH. M., And Reddy, C.V.G., 1973, Partition patterns of iron, manganese, nickel and cobalt in the shelf sediments off West coast of India: Indian Journal of Marine Sciences, v. 2, p. 6-12.

NaIR, R.R., AND PyleE, A., 1968, Size distribution and carbonate content of the sediments of the western shelf of India: Bullettin of National Institute of Sciences, India, v. 38, p. 411-420.

NAIR, R.R., HASHIMI, N.H., AND RAO, V.P., 1982a, Distribution and dispersal of clay minerals on the western continental shelf of India: Marine Geology, v. 50, p. M1-M9.

NAIR, R.R., HASHIMI, N.H., AND RAO, V.P., 1982b, On the possibility of high-velocity tidal streams as dynamic barriers to long shore sediment transport: evidence from the continental shelf off the Gulf of Kutch, India: Marine Geology, v. 47, p. 77-86.

NAQVI, S. W. A., 1987, Some aspects of the oxygen deficient conditions and denitrification in the Arabian Sea: Journal of Marine Research, v. 45, p. 1049-1072.

NAQVI, S.W.A., 1991, Geographical extent of denitrification in the Arabian Sea in relation to some physical processes: Oceanologica Acta, v. 14, p. 281-90.

NAQVI, S.W.A., 1994, Denitrification processes in the Arabian Sea: Proceedings of the Indian Academy of Science, v. 103, p. 181-202.

Naqvi, S.W.A., Jayakumar, D.A., NArVeKar, P.V., NAIK, H., SARMa, V.V.S.S., D’souZa, W., JosePh, S., AND GEORGE, M.D., 2000, Increased marine production of $\mathrm{N}_{2} \mathrm{O}$ due to intensifying anoxia on the Indian continental shelf: Nature, v. 408, p. 346-349.

Naqvi, S. W. A., Naik, H., Jayakumar, D. A., Shailaja, M. S., And Narvekar, P. V. 2006, Seasonal oxygen deficiency over the western continental shelf of India, In: Past and Present Water Column Anoxia, NATO Science Series, IV. Earth and Environmental Sciences, Neretin, L (Ed.) Springer, Dordrecht, Netherlands, v. 64, p. 195-224.

Nath, B.N., Roelandts, I., SudhaKar, M., AND PlÜGer, W.L., 1992, Rare earth element patterns of the Central Indian Basin sediments related to their lithology: Geophysical Research Letters, v. 19, p. 1197-1200.

NATH, B.N., BAU, M., RAO, B. R.., AND RAO, Ch. M., 1997, Trace and rare earth elemental variation in Arabian Sea sediments through a transect across the oxygen minimum zone: Geochimica et Cosmochimica Acta, v. 61, p. 2375-2388.

NAth, B.N., Kunzendorf, H., AND PlüGer, W.L., 2000, Influence of provenance, weathering and sedimentary processes on the elemental ratios of the fine-grained fraction of the bedload sediments from the Vembanad Lake and the adjoining continental shelf, southwest coast of India: Journal of Sedimentary Research, v. 70, p. 1081-1094.

Nath, B.N., Aldahan, A., Possnert, G., Selvaraj, K., Mascarenhas-Pereira, M.B.L., And Chen, C.T.A., 2007, ${ }^{10} \mathrm{Be}$ variation in surficial sediments of the Central Indian Basin: Nuclear 
Instruments and Methods in Physics Research (B: Beam Interactions with Materials and Atoms), v. 259, p. 610-615.

Nath, B.N., Makishima, A., Noordmann, J., TanaKa, R., And NaKamura, E., 2009, Comprehensive analysis for major, minor and trace element contents and $\mathrm{Sr}-\mathrm{Nd}-\mathrm{Pb}-\mathrm{Hf}$ isotope ratios in sediment reference materials, JSd-1 and MAG-1: Geochemical Journal, v. 44, p. 207-216.

Nesbitt, H.W., And Young, G. M. 1982, Early Proterozoic climates and plate motions inferred from major element chemistry of lutites: Nature, v. 299, p. 715-717.

Nesbitt, H.W., Markovics, G., AND Price, R.C., 1980, Chemical processes affecting alkalies and alkaline earths during continental weathering: Geochimica et Cosmochimica Acta, v. 44, p. 16591666.

Paropkari, A.L., Prakash Babu, C., And Mascarenhas, A. 1993, New evidence for enhanced preservation of organic carbon in contact with oxygen minimum zone on the western continental slope of India: Marine Geology, v. 111, p. 7-13.

Paropkari, A. L., Mascarenhas, A., Rao, Ch. M., Prakash Babu, C., and Murty, P. S. N., 1994, Elemental distributions in sediments and potential offshore mineral resources from the western continental margin of India: NIO/TR-4/94, p. 28.

Pedersen, T., F., Shimmield, G. B., And Price, N. B., 1992, Lack of enhanced preservation of organic matter in sediments under the oxygen minimum zone on the Oman margin: Geochimica et Cosmochimica Acta, v. 56, p. 545-551.

Peters, K.E., SweEney, R.E., KAPlan, I.R., 1978, Correlation of carbon and nitrogen stable isotopes in sedimentary organic matter: Limnology and Oceanography, v. 23, p. 598-604.

Prakash Babu, C., Brumsack, H.-J., AND Schnetger, B., 1999, Distribution of organic carbon in surface sediments along the eastern Arabian Sea: a revisit: Marine Geology, v. 162, p. 91-103.

QASIM, S.Z., 1982, Oceanography of the northern Arabian Sea: Deep Sea Research, v. 29, p. 1041-1068.

Ramaswamy, V., Nath, B.N., Vethamony, P., And Illangovan, D., 2007, Source and dispersal of suspended sediment in the macro-tidal Gulf of Kachchh: Marine Pollution Bullettin, v. 54, p. 708719.

Ramaswamy, V., Gaye, B., Shirodkar, P.V., RaO, P.S., Chivas, A.R., Wheeler, D., And Thwin, S., 2008, Distribution and sources of organic carbon, nitrogen and their isotopic signatures in sediments from the Ayeyarwady (Irrawaddy) continental shelf, northern Andaman Sea: Marine Chemistry, v. 111, p. 137-150.

RAmesh, R., AND Subramanian, V., 1988, Nature of the dissolved load of the Krishna river basin, India: Journal of Hydrology, v.103, p. 139-155.

RAO, B, R., AND VEERAYYA, M., 2000, Influence of marginal highs on the accumulation of organic carbon along the continental slope of western India: Deep Sea Research, II, v. 47, p. 303-327. 
RAO, V.P., 1991, Clay mineral distribution in the continental shelf and slope off Saurashtra, west coast of India: Indian Journal of Marine Sciences, v. 20, p. 1-6.

RAO, V.P., AND RAO, B.R., 1995, Provenance and distribution of clay minerals in the sediments of the western continental shelf and slope of India: Continental Shelf Research, v. 15, p. 1757-1771.

RAO, V.P., AND WAGLE, W.G., 1997, Geomorphology and surficial geology of the western continental shelf and slope of India: A review: Current Science, v. 73, p. 330-350.

REICHART, G.J., 1997, Late Quaternary variability of the Arabian Sea monsoon and oxygen minimum zone: $\mathrm{Ph}$. D. thesis, University of Utrecht, Netherlands.

SCHÄFER, P., AND ITTEKKoT, V., 1995, Isotopic biogeochemistry of nitrogen in the northern Indian Ocean: Mitt. Geol.-Palaont. Inst. Univ. Hamburg, v. 78, p. 67-93.

SCHLÜNZ, B., AND SCHNEIDER, R.R., 2000, Transport of terrestrial organic carbon to the oceans by rivers: re-estimating flux and burial rates: International Journal of Earth Sciences, v. 88, p. 599606.

Selvaraj, K., AND CHEN, C.T.A., 2006, Moderate chemical weathering of subtropical Taiwan: constraints from solid-phase geochemistry of sediments and sedimentary rocks: The Journal of Geology, v. 114, p. 101-116.

Sen Gupta, R., Sankaranarayanan, V. N., Desousa, S. N., And Fondekar, S. P. 1976, Chemical Oceanography of the Arabian Sea. Part-III, Studies on nutrient fraction and stoichiometric relationships in the northern and eastern basin: Indian Journal of Marine Sciences, v. 5, p. 58-71.

Shankar, R., SubbaraO, K.V., And Kolla, V., 1987, Geochemistry of surface sediments from the Arabian Sea: Marine Geology, v. 76, p. 253-279.

SHARMA A., AND RAJAMANI, V. 2000, Weathering of gneissic rocks in the upper reaches of Cauvery River, South India: implications to neotectonics of the region: Chemical Geology, v. 166, p. 203223.

SIBY, V., 2004, Geochemistry of rare earth elements and trace metals along the western continental shelf of India: Ph.D thesis, Cochin University of Science and Technology, Kerala (unpublished), p.238.

Singh, P., AND RAJAMANi, V., 2001a, REE geochemistry of recent clastic sediments from the Kaveri floodplains, Southern India: implication to source area weathering and sedimentary processes: Geochimica et Cosmochimica Acta, v. 65, p. 3093-3108.

Singh, P., And Rajamani, V., 2001b, Geochemistry of the Kaveri flood-plain sediments, Southern India: Journal of Sedimentary Research, v. 71, p. 50-60.

Sirocko, F., Schonberg, D.G., And Devey, C., 2000, Processes controlling trace element geochemistry of Arabian Sea sediments during the last 25,000 years: Global and Planetary Change, v. 26, p. 217303.

SNOECKX, H., AND REA D.K., 1994, Dry bulk density and $\mathrm{CaCO}_{3}$ relationships in upper Quaternary sediments of the eastern equatorial Pacific: Marine Geology, v. 120, p. 327-333. 
Staubwasser, M., AND Sirocko, F., 2001, On the formation of laminated sediments on the continental margin off Pakistan: the effects of sediment provenance and sediment redistribution: Marine Geology, v. 172, p. 43-56.

Stewart, R.H., Pilkey, O.H., AND Nelson, B.C., 1965, Sediments of the northern Arabian Sea: Marine Geology, v. 3, p. 411-427.

Sun S-S., And McDonough, W. F., 1989, Chemical and isotopic systematics of oceanic basalts: implications for mantle compositions and processes: In: Saunders, A. D., and Norry, M. J. (Eds.) Magmatism in the ocean basins: Geological Society of London, p. 313-345.

TAYLOR, S.R., AND MCLENNAN, S.M., 1985, The continental crust: its composition and evolution, Blackwell Scientific Publications, Oxford, p.312.

Terashima, S., Imai, N., Taniguchi, M., OKai, T., And Nishimura, A., 2002, The preparation and preliminary characterisation of four new Geological Survey of Japan geochemical reference materials: Soils, JSO-1 and JSO-2; and marine sediments, JMS-1 and JMS-2: Geostandards Newsletter: The Journal of Geostandards and Geoanalysis, v. 26, p. 85-94.

VAN Der WeIJDEn, C.H., REICHART, G.J., AND VISSER, H.J., 1999, Enhanced preservation of organic matter in sediments deposited within the oxygen minimum zone in the northeastern Arabian Sea: Deep Sea Research, v. 46, p. 807-830.

WedePOHL, K.H., 1969, The Handbook of Geochemistry, v. 1. Springer-Verlag, Berlin, p- 247.

WeDEPOHL, K.H., 1970, In: Handbook of Geochemistry, v. II/2. Springer-Verlag, Berlin, p. 37 B 1-37 K3.

Wronkiewicz, D.J. AND CondiE, K.C., 1990, Geochemistry and mineralogy of sediments from the Ventersdorp and Transvaal Supergroups, South Africa: Early Proterozoic evolution of the Kaapvaal Craton: Geochimica et Cosmochimica Acta, v. 54, p. 343-354.

WU, Y., ZHANG, J., ZHANG, Z.F., REN, J.L., AND CAO, J.P., 2002, Seasonal variability of stable carbon and nitrogen isotope of suspended particulate matter in the Changjiang River: Oceanologia et Limnologia Sinica, v. 33, p. 546-552.

WYRTKI, K., 1971, Oceanographic Atlas of the International Indian Ocean Expedition: Washington D.C. National Science Foundation, p -531. 


\section{Figure captions:}

Figure 1: (a) Sediment type distribution in the western continental margin of India (modified from Kessarkar et al. 2003); (b) Geology of source terrain with sampling locations (red circles from south of Goa having provenance of granulitic terrain, while blue circles from north of Goa having Deccan trap basaltic provenance); (c) Latitudinal variability of major element oxides $\left(\mathrm{SiO}_{2}, \mathrm{TiO}_{2}\right.$ and $\mathrm{MgO}$ in \%) and trace element $\mathrm{Rb}(\mathrm{ppm})$ in sediments from $30 \mathrm{~m}$ and $50 \mathrm{~m}$ depths, the elements diagnostic of source composition. Elemental contents are distinctly different in sediments from south and north of Goa reflecting the differences in provenance characteristics.

Figure 2: Transect wise shale (PAAS) normalized REE patterns of sediments (REE content on carbonate free basis $-c f b)$. Also shown are the patterns of possible source material viz., Deccan Trap basalts (Lightfoot et al. 1990), Indus suspended sediments (Goldstein and Jacobsen 1988) and gneisses and charnockites from south India (Allen et al. 1985) from the published literature. While the patterns of sediments off GOA, RAT, VER resemble those of Deccan Trap basalts, some influence of Indus is seen in sediments off DWA, POR and MUM. In the southern transects (KOCHI and KOLLAM), LREE enriched patterns are similar to charnockites and gneisses of South Indian Precambrian crystalline terrains. Probable influence of Bay of Bengal is also seen in sediments from the southern tip of India (CAPE COM).

Figure 3: Plot showing $\mathrm{Na}_{2} \mathrm{O}+\mathrm{K}_{2} \mathrm{O}$ vs. $\mathrm{SiO}_{2}$. Also shown are possible fields of unweathered rocks of ultrabasic, basic, intermediate and acidic type based on silica content (Le Maitre et al. 1989). Samples from north of Goa falls in the basaltic or basaltic andesite field, distinctly separating the sediments south of Goa which fall in silica-rich domain consistent with our interpretation.

Figure 4: Chondrite-normalized spidergrams of geochemical data of sediments from 30m water depths (chondrite values from Sun and McDonough 1989; elemental values on $c f b$ ) show distinctly different patterns for the sediments south and north of Goa. Except at phosphorus, higher values are seen for all the elements in sediments north of Goa.

Figure 5: La-Th-Sc Ternary diagram (data on $c f b$ ) showing the provenance characteristics of the sediments from two regions (north of Goa and south of Goa). Granite, Tonalite and basalt (Tholeiite) are also plotted (values taken from Wronkiewicz and Condie, 1990). Sediments south of Goa fall closer to 
the granite and those from north of Goa plot away from granite, variation guided by changes in Th and Sc content.

Figure 6: (a) Variability in Chemical Index of Alteration (CIA) and (b) Plagioclase Index of Alteration (PIA) values (calculated using formulae of Nesbitt and Young (1982) and Fedo et al. (1995) respectively). Higher alteration values are noticed in a patch between Mumbai and Mormugao and also between Mangalore and Kannur.

Figure 7: (a) Ternary plots of $\mathrm{Al}_{2} \mathrm{O}_{3}-\left(\mathrm{CaO}+\mathrm{Na}_{2} \mathrm{O}\right)-\mathrm{K}_{2} \mathrm{O}(\mathrm{A}-\mathrm{CN}-\mathrm{K})$ and (b) $\left(\mathrm{Al}_{2} \mathrm{O}_{3}-\mathrm{K}_{2} \mathrm{O}\right)-\mathrm{CaO}-$ $\mathrm{Na}_{2} \mathrm{O}$ (A-C-N) in molar proportions reflecting the intensity of weathering. Scale of CIA and PIA are shown at right. While most of the sediments fall between CIA 60 and 80, indicating moderate intensity of silicate weathering, few sediments from central west coast of India (as detailed in the text) fall close to the $\mathrm{Al}_{2} \mathrm{O}_{3}$ (a) or $\mathrm{Al}_{2} \mathrm{O}_{3}-\mathrm{K}_{2} \mathrm{O}$ (b) apex suggesting their extremely altered nature. The diagram also shows the field of minerals: Illite, $\mathrm{Pl}=$ plagioclase, $\mathrm{Ks}=\mathrm{K}$-feldspar, $\mathrm{Sm}=$ Smectite, $\mathrm{Ka}=\mathrm{Kaolinite}, \mathrm{Gi}=$ Gibbsite, $\mathrm{Chl}=$ Chlorite, $\mathrm{An}=$ Anorthite, $\mathrm{Al}=$ Albite.

Figure 8: Distributional trends of $\delta^{13} \mathrm{C}$ (a) and $\delta^{15} \mathrm{~N}$ (b) in \%o of organic matter along the western continental shelf of India. The map shows our $\delta^{13} \mathrm{C}$ data along with data compiled from published literature (Fontugne and Duplessy 1986; Agnihotri et al. 2003; Mazumdar et al. 2009 and Cowie et al. 2009). Though, $\delta^{13} \mathrm{C}$ values of all the samples depict marine signature, comparatively higher values are seen off Gujarat (POR, DWA and VER) possibly because of C-4 vegetation sources on land, vegetation consistent with soil type and source terrain geology.

Figure 9: Plot of $\delta^{13} \mathrm{C}$ versus $\mathrm{C} / \mathrm{N}_{\text {molar }}$ ratio of the sediments from $30 \& 50,100$ and $200 \mathrm{~m}$ depths. Coastal sediments (30m depth) show distinct north-south provinciality in $\delta^{13} \mathrm{C}$ values (with divide at a value of -21.5), which is similar to inorganic geochemical data. A clear north-south provinciality, however, is not visible for sediments from deeper areas. 


\section{Figure 1}
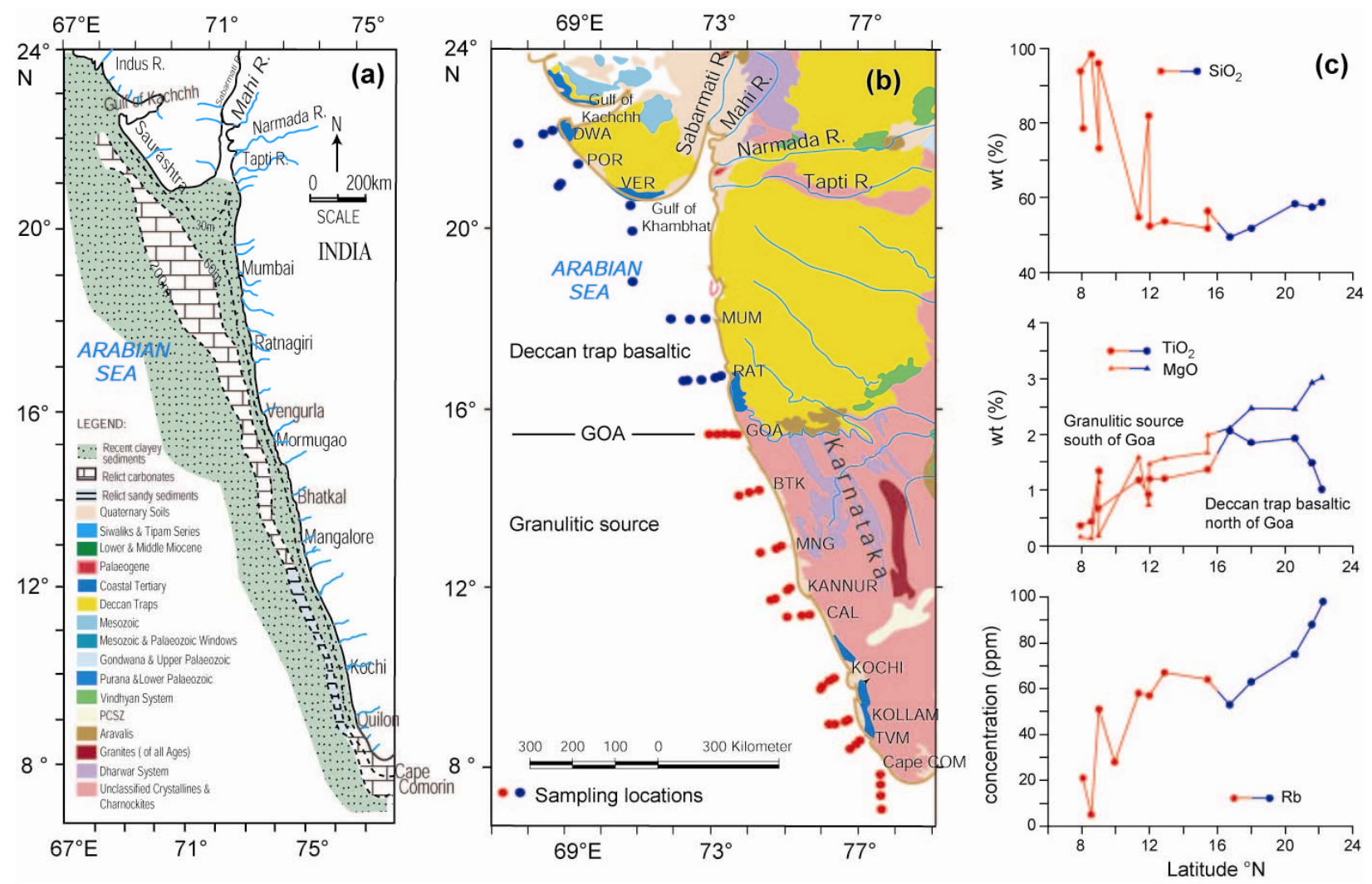


\section{Figure 2}
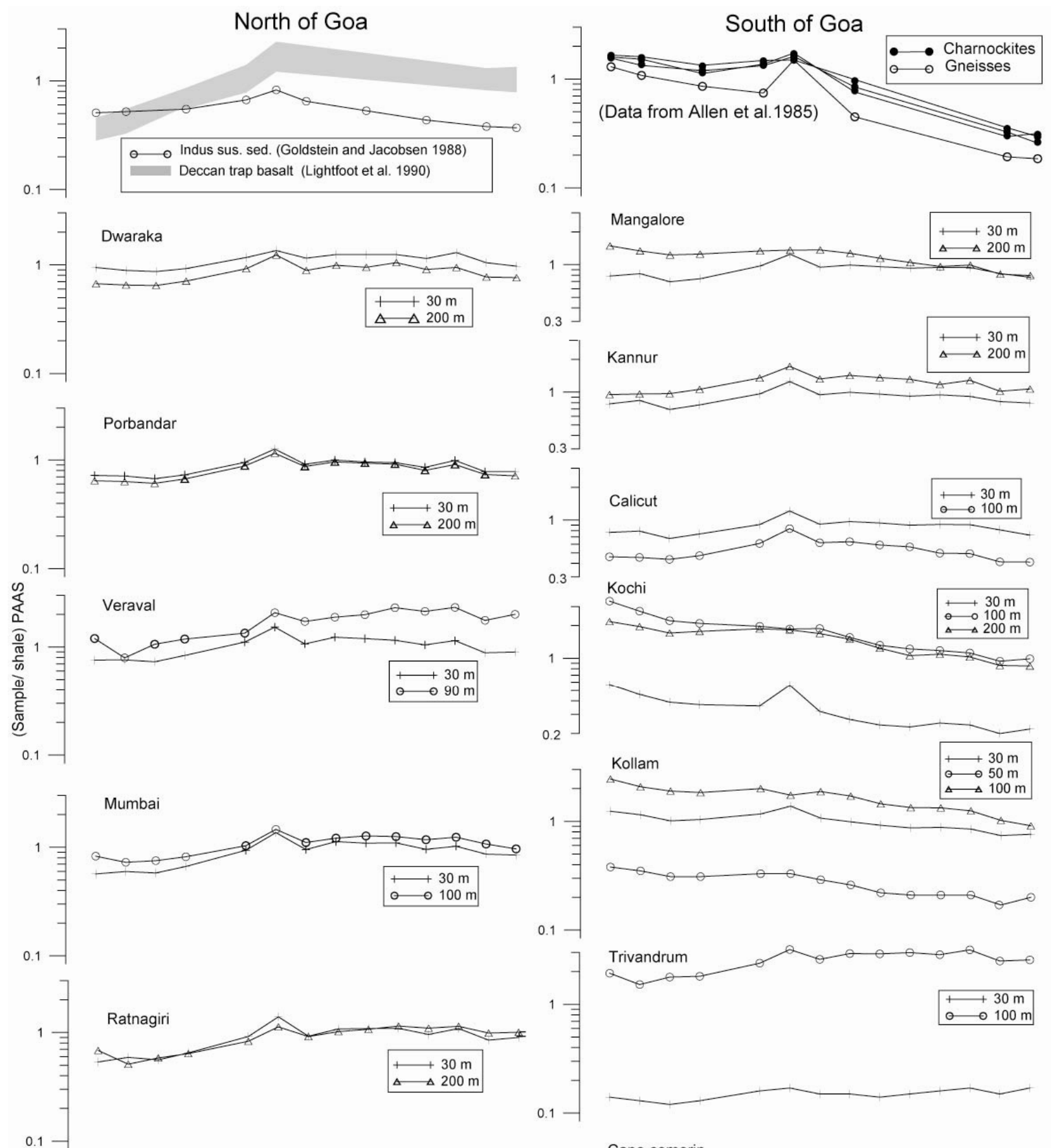

$0.3]$
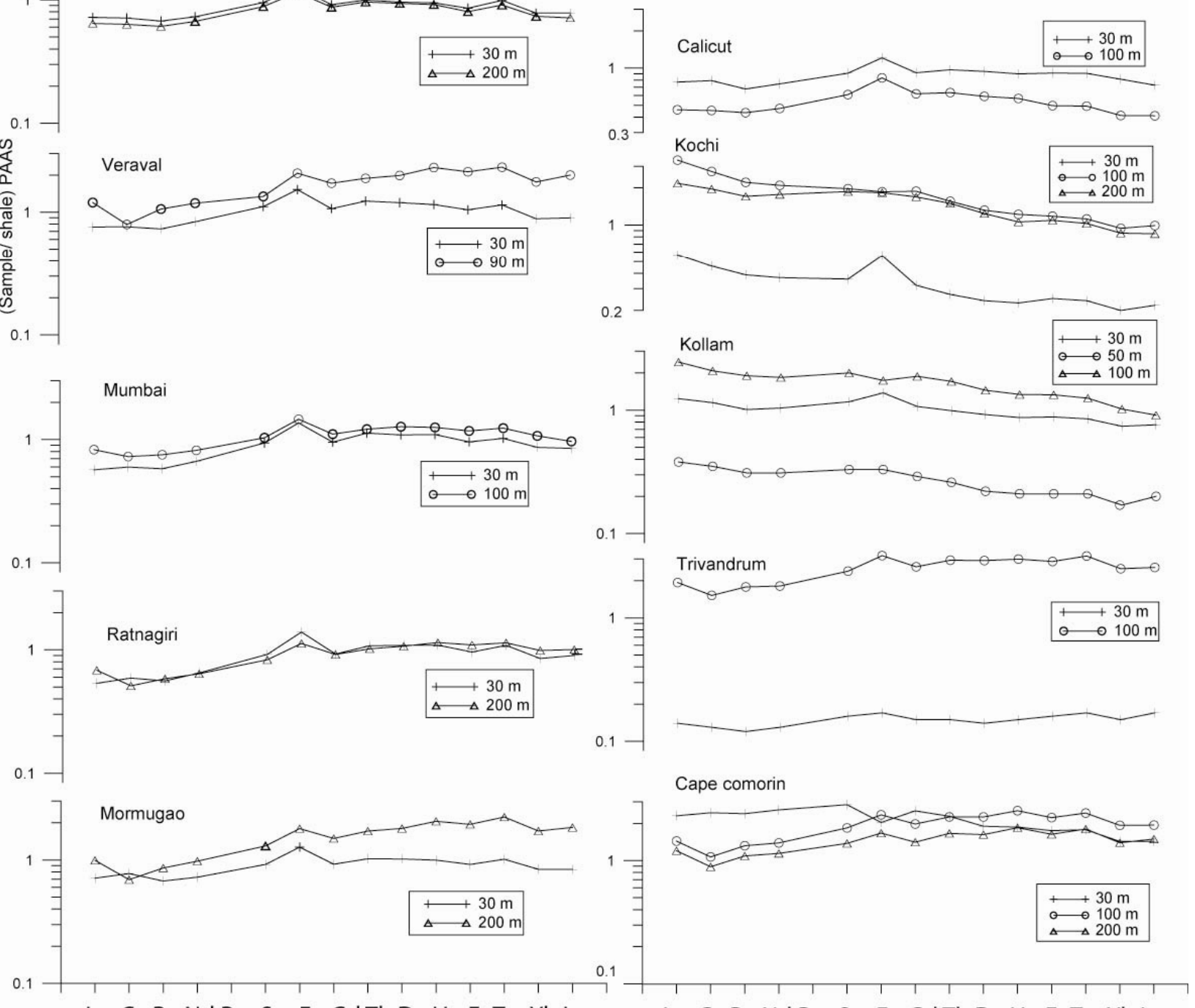

La Ce Pr Nd Pm Sm Eu Gd Tb Dy Ho Er Tm Yb Lu

La Ce Pr Nd Pm Sm Eu Gd Tb Dy Ho Er Tm Yb Lu 
Figure 3

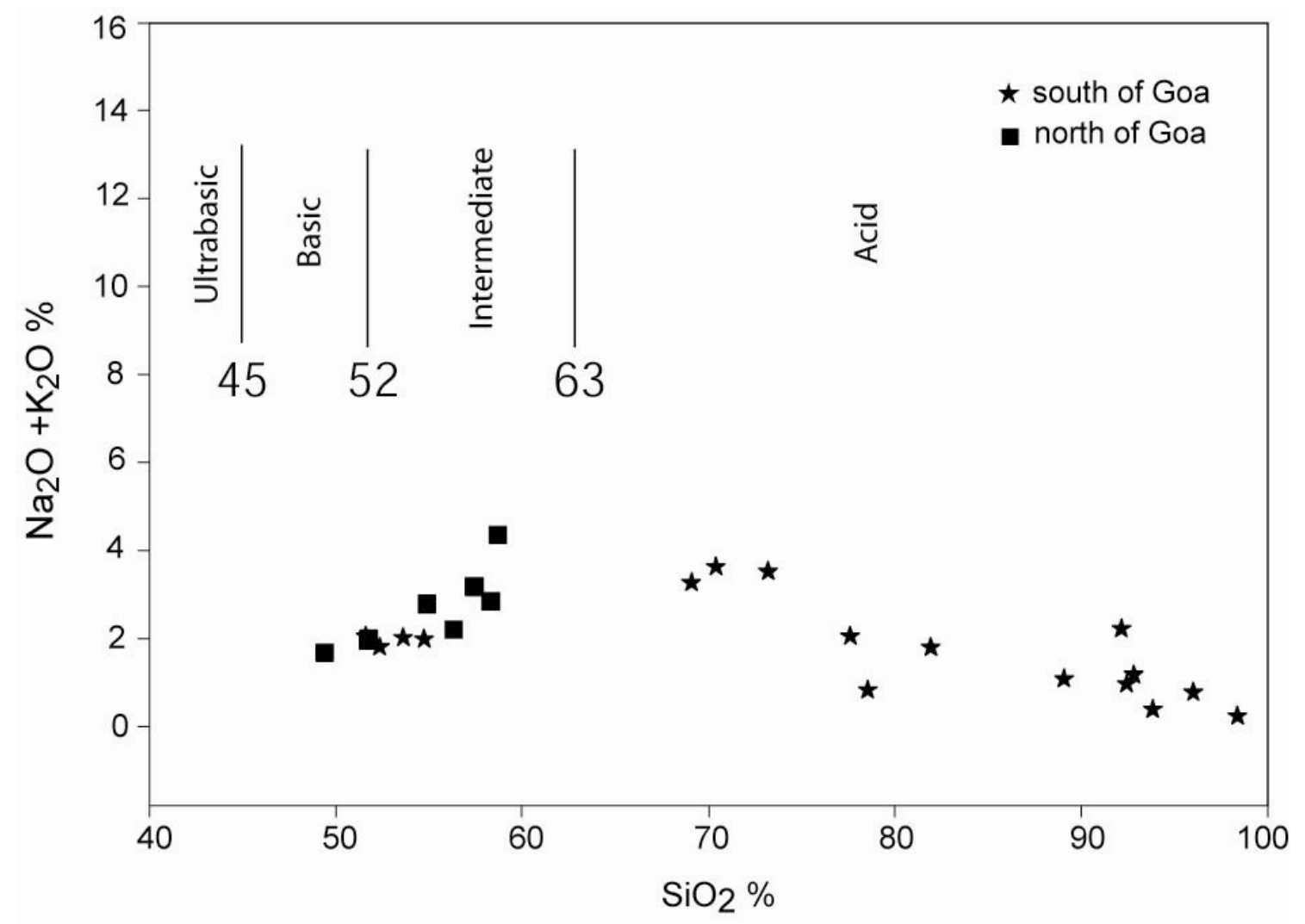

Figure 4

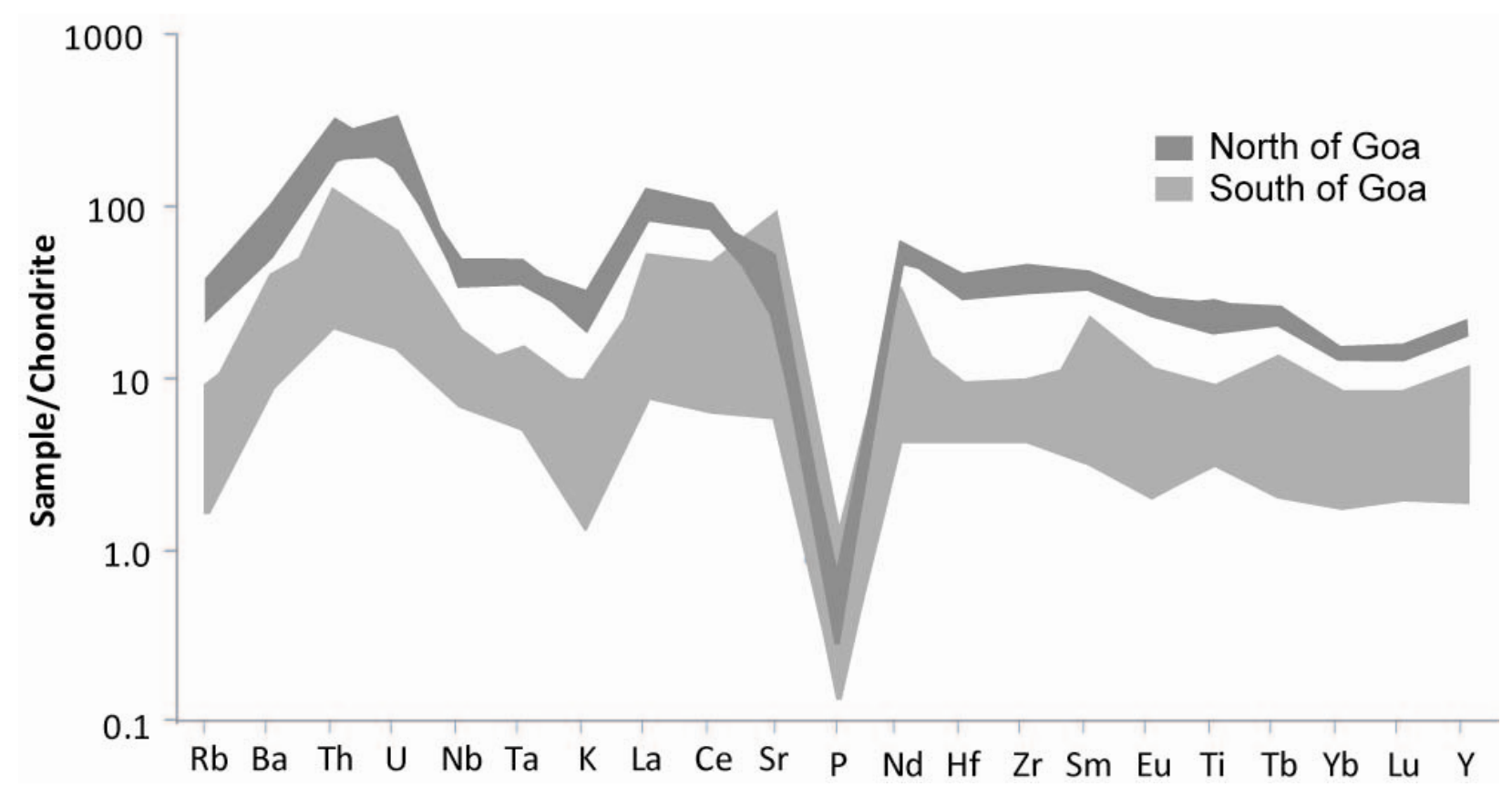


Figure 5

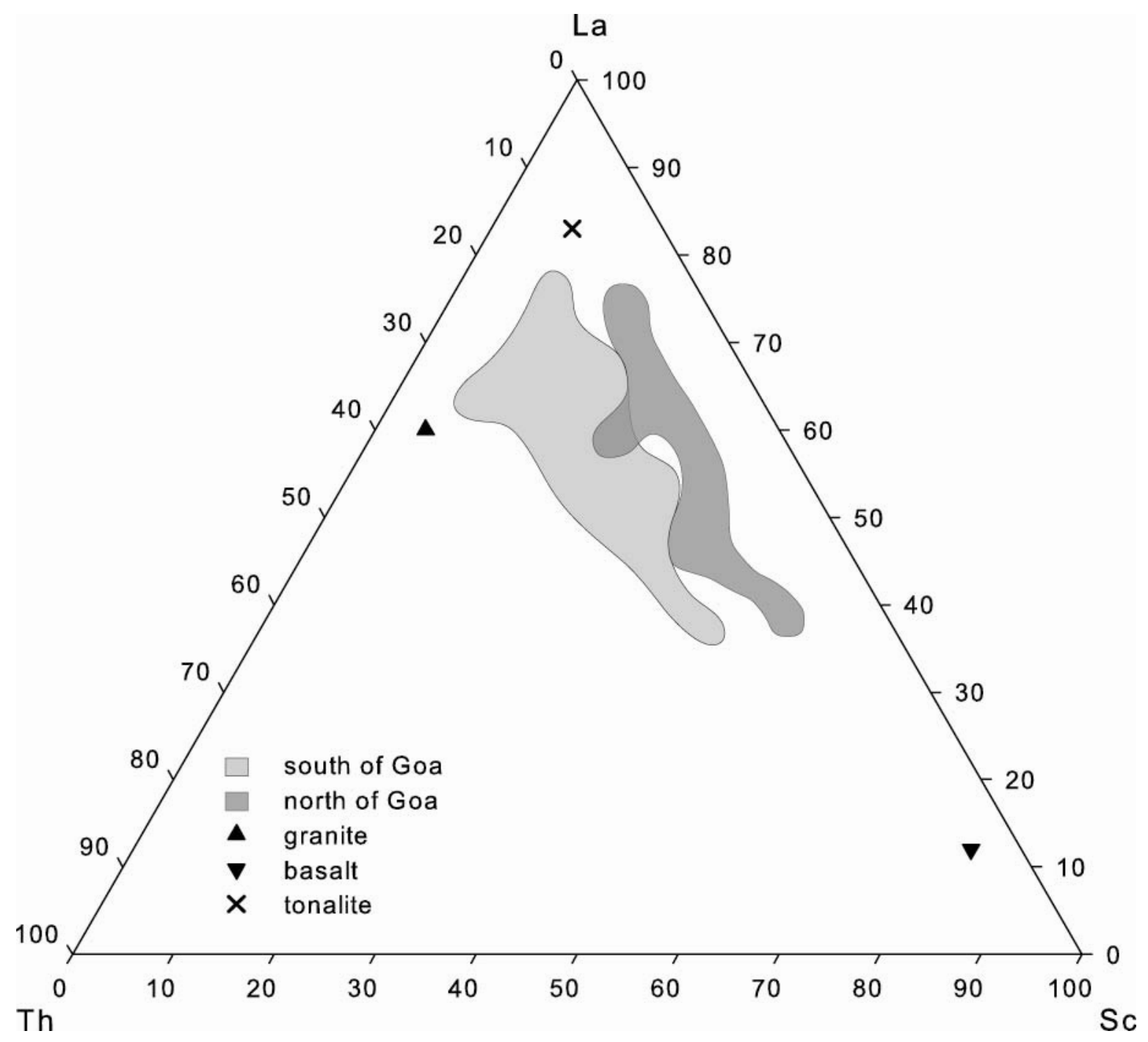


Figure 6
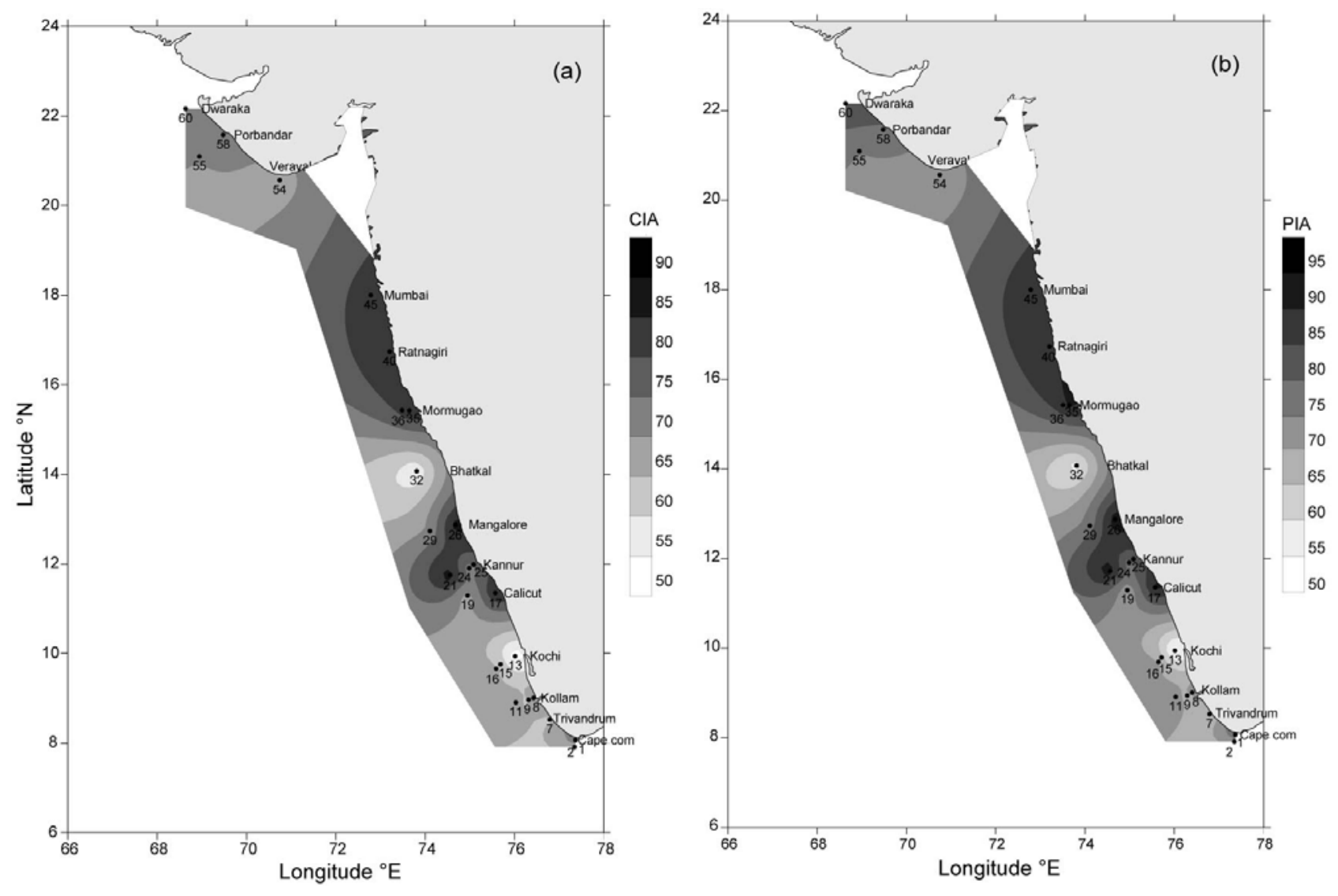
Figure 7
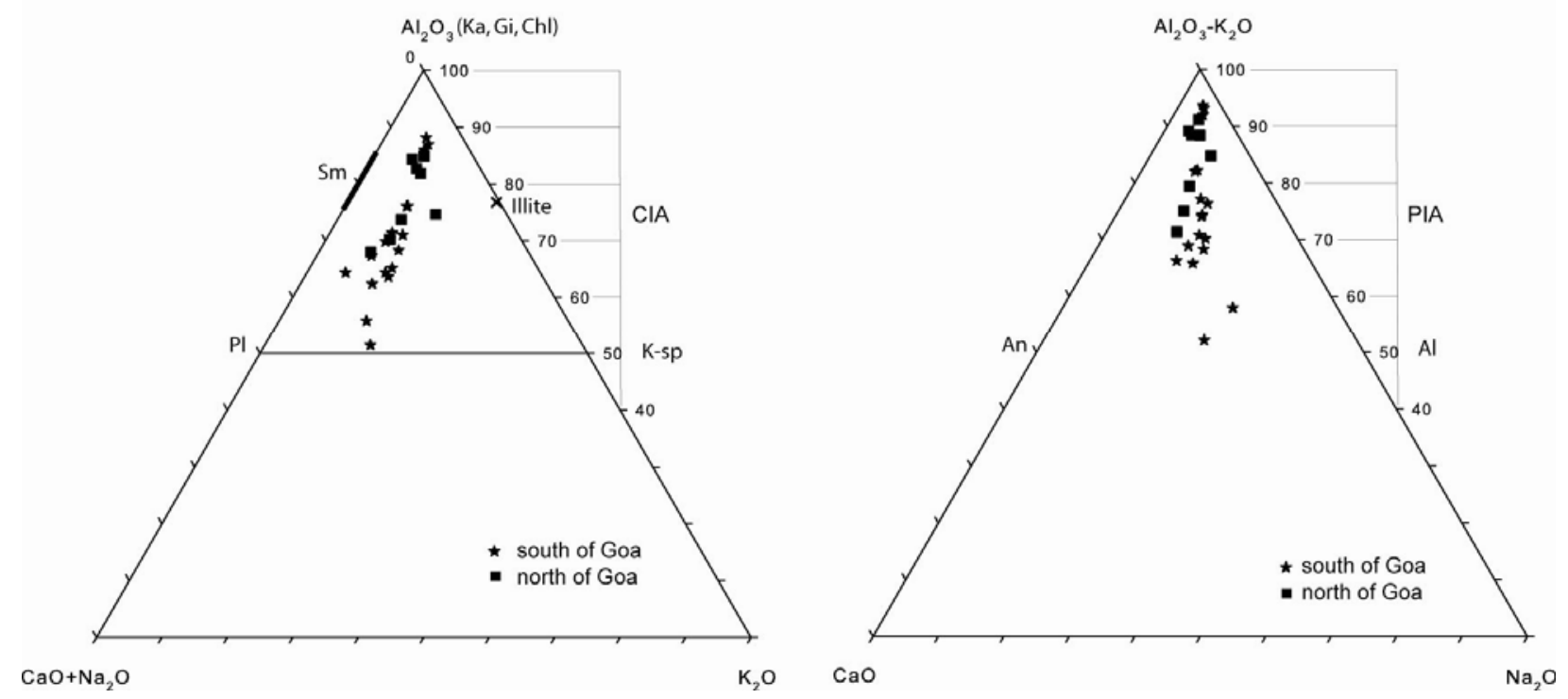

Figure 8
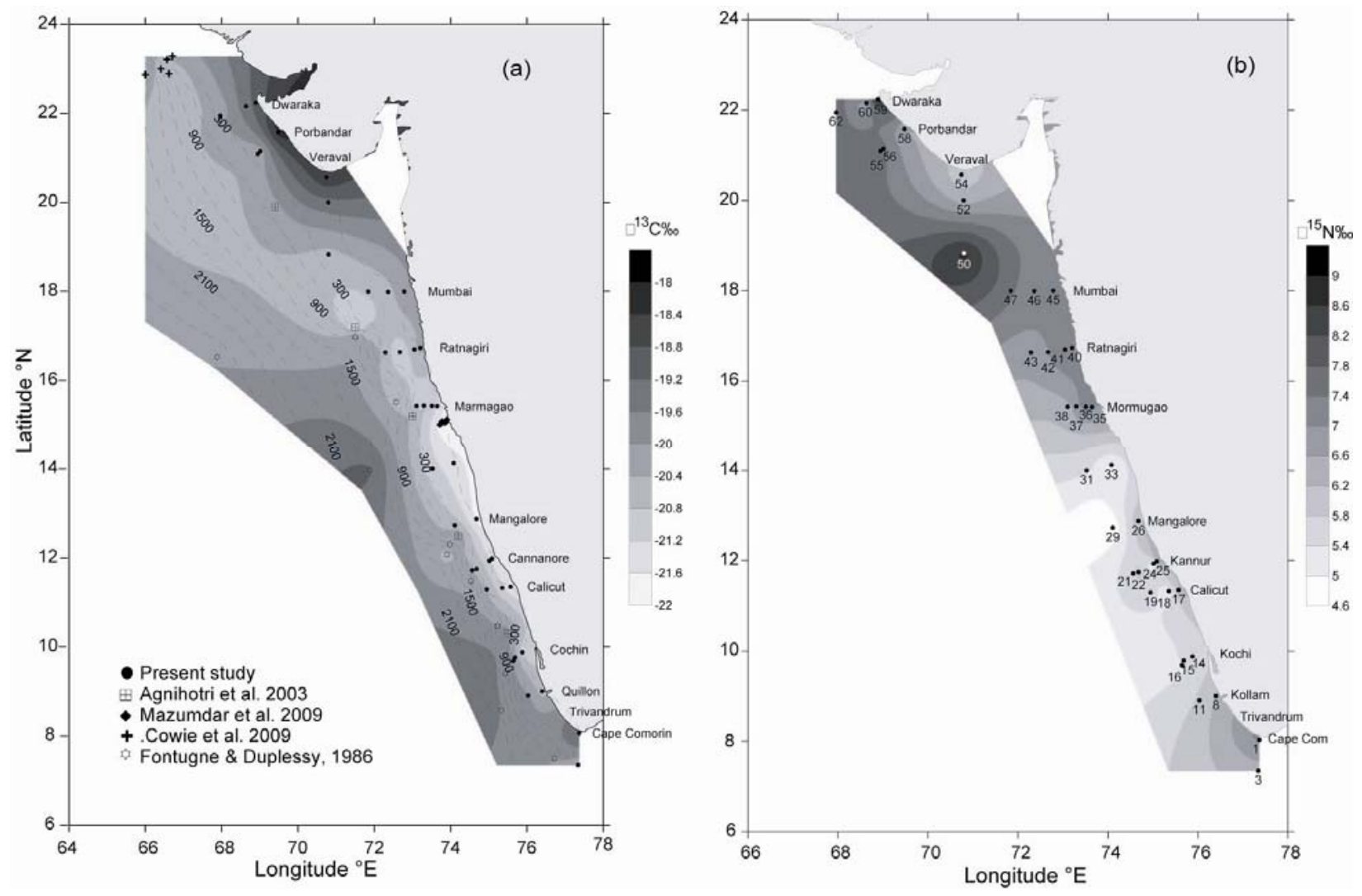
Figure 9

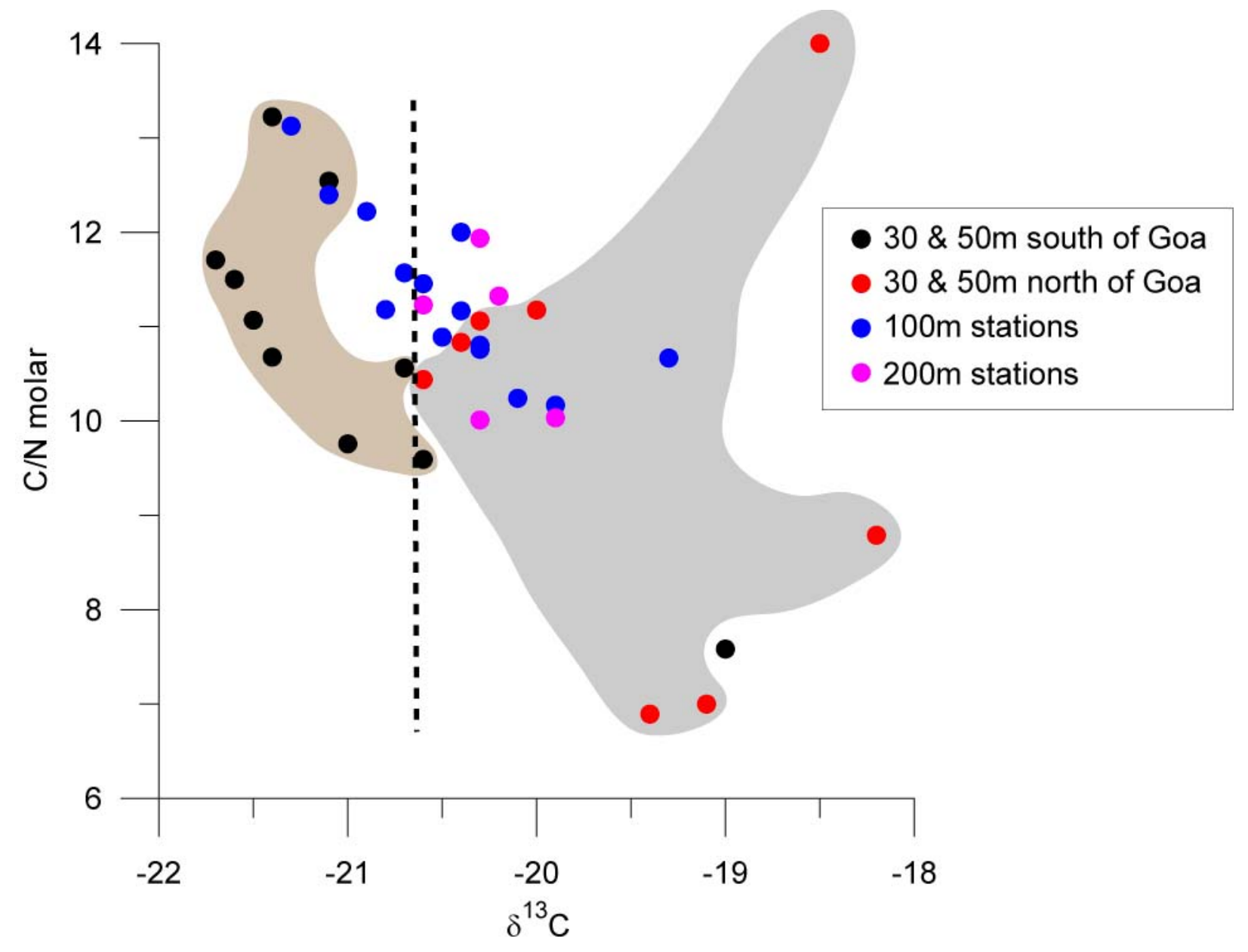


Table 1. Location (abbreviation) of surface sediment samples and bottom water dissolved oxygen (DO) concentration at the stations

\begin{tabular}{|c|c|c|c|c|c|}
\hline St. No. & Stations & $\begin{array}{l}\text { Depth } \\
\text { (m) }\end{array}$ & Lat ${ }^{\circ} \mathrm{N}$ & Long ${ }^{\circ} \mathrm{E}$ & $\begin{array}{c}\text { DO } \\
(\mathrm{ml} / \mathrm{L})\end{array}$ \\
\hline \multicolumn{6}{|c|}{ Southern Transects } \\
\hline 1 & \multirow{4}{*}{$\begin{array}{l}\text { Cape Comorin (Cape } \\
\text { COM) }\end{array}$} & 30 & 8.07 & 77.37 & 3.25 \\
\hline 2 & & 50 & 7.91 & 77.34 & 3.14 \\
\hline 3 & & 100 & 7.35 & 77.34 & 0.86 \\
\hline 4 & & 200 & 7.17 & 77.33 & 0.14 \\
\hline 7 & \multirow{3}{*}{ Trivandrum (TVM) } & 30 & 8.55 & 76.82 & 3.28 \\
\hline 6 & & 60 & 8.46 & 76.71 & 3.69 \\
\hline 5 & & 125 & 8.36 & 76.55 & 0.26 \\
\hline 8 & \multirow{4}{*}{ Kollam (KOLLAM) } & 30 & 9.01 & 76.4 & 3.33 \\
\hline 9 & & 50 & 8.97 & 76.31 & 3.08 \\
\hline 11 & & 100 & 8.91 & 76.03 & 1.45 \\
\hline 12 & & 230 & 8.91 & 75.98 & 0.24 \\
\hline 13 & \multirow{4}{*}{ Kochi (KOCHI) } & 30 & 9.94 & 76.01 & 3.3 \\
\hline 14 & & 50 & 9.88 & 75.88 & 3.35 \\
\hline 15 & & 100 & 9.76 & 75.69 & 1.5 \\
\hline 16 & & 200 & 9.69 & 75.64 & 0.13 \\
\hline 17 & \multirow{3}{*}{ Calicut (CAL) } & 30 & 11.35 & 75.57 & 3.2 \\
\hline 18 & & 50 & 11.33 & 75.35 & 3.07 \\
\hline 19 & & 100 & 11.3 & 74.95 & 1.7 \\
\hline 25 & \multirow{4}{*}{ Kannur (KANNUR) } & 30 & 11.99 & 75.08 & 3.17 \\
\hline 24 & & 50 & 11.94 & 75.01 & 3.1 \\
\hline 22 & & 100 & 11.75 & 74.68 & 2.92 \\
\hline 21 & & 200 & 11.72 & 74.56 & 0.06 \\
\hline 26 & \multirow{3}{*}{ Mangalore (MNG) } & 30 & 12.88 & 74.68 & 3.7 \\
\hline 27 & & 50 & 12.82 & 74.54 & 3.11 \\
\hline 29 & & 200 & 12.73 & 74.11 & 0.04 \\
\hline 33 & \multirow{3}{*}{ Bhatkal (BTK) } & 50 & 14.12 & 74.08 & 3.42 \\
\hline 32 & & 60 & 14.07 & 73.81 & 2.29 \\
\hline 31 & & 100 & 14 & 73.53 & 2.46 \\
\hline
\end{tabular}




\begin{tabular}{|c|c|c|c|c|c|}
\hline \multicolumn{2}{|c|}{ Northern Transects } & & & & \\
\hline 35 & \multirow{5}{*}{ Mormugao (GOA) } & 30 & 15.42 & 73.65 & 2.99 \\
\hline 36 & & 50 & 15.43 & 73.51 & 3 \\
\hline 37 & & 70 & 15.44 & 73.3 & 1.66 \\
\hline 38 & & 100 & 15.43 & 73.11 & 1.52 \\
\hline 39 & & 200 & 15.43 & 72.88 & 0.03 \\
\hline 40 & \multirow{5}{*}{ Ratnagiri (RAT) } & 30 & 16.73 & 73.2 & 3.2 \\
\hline 41 & & 50 & 16.69 & 73.05 & 3.2 \\
\hline 42 & & 75 & 16.64 & 72.67 & 1.85 \\
\hline 43 & & 100 & 16.63 & 72.29 & 0.75 \\
\hline 44 & & 200 & 16.62 & 72.18 & 0.04 \\
\hline 45 & \multirow{3}{*}{ Mumbai (MUM) } & 30 & 18 & 72.78 & 3.39 \\
\hline 46 & & 50 & 17.99 & 72.36 & 3.35 \\
\hline 47 & & 100 & 18 & 71.84 & 2.07 \\
\hline 54 & \multirow{3}{*}{ Veraval (VER) } & 30 & 20.57 & 70.74 & 3.46 \\
\hline 52 & & 80 & 20 & 70.79 & 3.35 \\
\hline 50 & & 100 & 18.83 & 70.8 & 2.62 \\
\hline 58 & \multirow{3}{*}{ Porbandar (POR) } & 30 & 21.58 & 69.48 & 3.59 \\
\hline 56 & & 100 & 21.15 & 69.01 & 2.94 \\
\hline 55 & & 200 & 21.09 & 68.95 & 0.02 \\
\hline 59 & \multirow{3}{*}{ Dwaraka (DWA) } & 30 & 22.24 & 68.89 & 3.56 \\
\hline 60 & & 50 & 22.16 & 68.64 & 3.57 \\
\hline 62 & & 200 & 21.95 & 67.96 & 0.03 \\
\hline
\end{tabular}


Table 2. Analytical data of international geochemical reference material, along with accuracy and precision data of the analyses

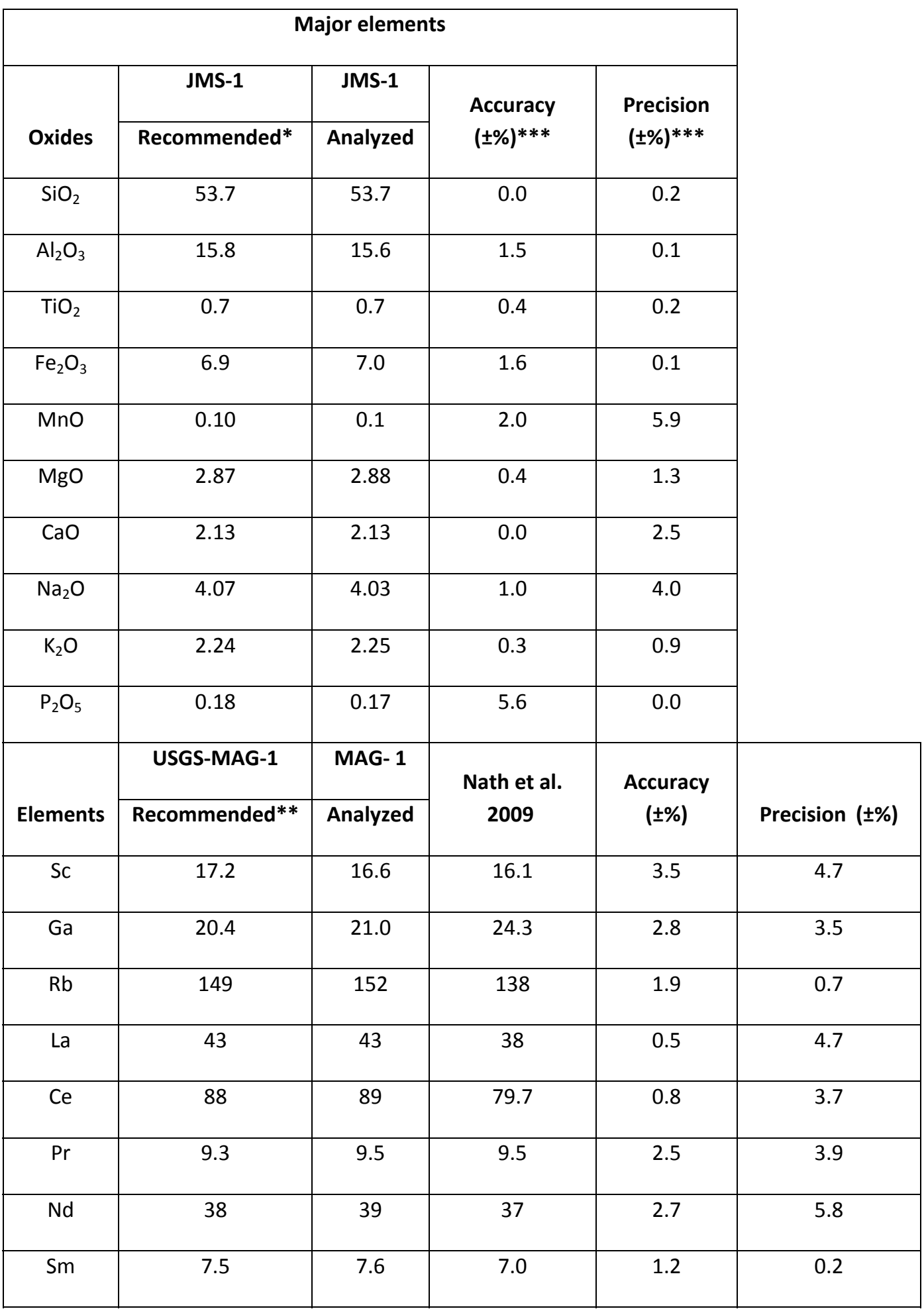




\begin{tabular}{|c|c|c|c|c|c|}
\hline $\mathrm{Eu}$ & 1.55 & 1.63 & 1.4 & 5 & 4.8 \\
\hline $\mathrm{Gd}$ & 5.8 & 6.0 & 6.6 & 4.1 & 3.3 \\
\hline $\mathrm{Tb}$ & 0.96 & 0.99 & 0.91 & 3.1 & 0.5 \\
\hline Dy & 5.2 & 5.3 & 5.2 & 2.6 & 4.8 \\
\hline $\mathrm{Ho}$ & 1.02 & 1.05 & 0.98 & 3.2 & 3.2 \\
\hline $\mathrm{Er}$ & 3 & 2.9 & 2.7 & 2.2 & 6.6 \\
\hline $\mathrm{Tm}$ & 0.43 & 0.46 & 0.39 & 6.5 & 4.7 \\
\hline $\mathrm{Yb}$ & 2.6 & 2.6 & 2.5 & 0 & 0.6 \\
\hline Lu & 0.4 & 0.4 & 0.38 & 3 & 5.8 \\
\hline Th & 11.9 & 12.4 & 12 & 3.9 & 1.9 \\
\hline $\mathrm{Ba}$ & 479 & 480 & 405 & 0.2 & 5.8 \\
\hline$U$ & 2.7 & 2.8 & 2.8 & 4.9 & 1.5 \\
\hline $\mathrm{Nb}$ & 12 & 12 & 13 & 0.9 & 7.6 \\
\hline $\mathrm{Ta}$ & 1.1 & 1.1 & 0.9 & 3.1 & 9.5 \\
\hline $\mathrm{Sr}$ & 146 & 149 & 138 & 2.3 & 0.0 \\
\hline $\mathrm{Hf}$ & 3.7 & 3.8 & 3.2 & 1.8 & 0.8 \\
\hline $\mathrm{Zr}$ & 126 & 129 & 117 & 2.2 & 4.5 \\
\hline$Y$ & 28 & 29 & 23 & 2.8 & 1.6 \\
\hline
\end{tabular}

*Terashima et al. 2002; ** Govindaraju 1994,***Accuracy $=\{$ Mean value - Recommended value $\} \mathrm{x}$ $\underline{100,}$

Recommended value

Precision $=\{$ Measured 1- Measured 2 $\} \times 100$

Measured 1 
Table 3. Concentration of major element oxides (\%) in salt- and carbonate-free sediments (representing lithogenic fraction) and weathering indices (CIA and PIA; formula given in the text)

\begin{tabular}{|c|c|c|c|c|c|c|c|c|c|c|c|c|c|c|c|}
\hline St. No. & Stations & $\begin{array}{c}\text { Depth } \\
\text { m }\end{array}$ & $\begin{array}{c}\text { SiO } \\
2\end{array}$ & $\begin{array}{c}\mathrm{Al}_{2} \mathrm{O} \\
3\end{array}$ & $\begin{array}{c}\text { TiO } \\
2\end{array}$ & $\begin{array}{c}\mathrm{Fe}_{2} \mathrm{O} \\
3\end{array}$ & $\begin{array}{c}M n \\
0\end{array}$ & $\begin{array}{c}\mathrm{Mg} \\
\mathrm{O}\end{array}$ & $\begin{array}{c}\mathrm{Ca} \\
\mathrm{O}\end{array}$ & $\begin{array}{c}\mathrm{Na}_{2} \\
\mathrm{O}\end{array}$ & $\mathrm{K}_{2} \mathrm{O}$ & $\begin{array}{c}\mathrm{P}_{2} \mathrm{O} \\
{ }_{5}\end{array}$ & CIA & PIA & $\begin{array}{c}\mathrm{K}_{2} \mathrm{O} / \mathrm{Na}_{2} \\
\mathrm{O}\end{array}$ \\
\hline 1 & CAPE & 30 & $\begin{array}{c}78 . \\
5\end{array}$ & 5.0 & $\begin{array}{c}2.0 \\
1\end{array}$ & 9.53 & 0.03 & 1.43 & $\begin{array}{c}0.2 \\
9\end{array}$ & 0.27 & $\begin{array}{c}0.5 \\
7\end{array}$ & $\begin{array}{c}0.3 \\
6\end{array}$ & $\begin{array}{c}76 . \\
0\end{array}$ & $\begin{array}{c}82 . \\
0\end{array}$ & 2.14 \\
\hline 2 & & 50 & $\begin{array}{c}93 . \\
8\end{array}$ & 1.5 & $\begin{array}{c}0.3 \\
6\end{array}$ & 1.47 & 0.00 & 0.16 & $\begin{array}{c}0.1 \\
7\end{array}$ & 0.14 & $\begin{array}{c}0.2 \\
5\end{array}$ & $\begin{array}{c}0.0 \\
5\end{array}$ & $\begin{array}{c}64 . \\
4\end{array}$ & $\begin{array}{c}68 . \\
9\end{array}$ & 1.74 \\
\hline 7 & TVM & 30 & $\begin{array}{c}98 . \\
4\end{array}$ & 1.2 & $\begin{array}{c}0.4 \\
3\end{array}$ & 0.88 & 0.00 & 0.13 & $\begin{array}{c}0.1 \\
9\end{array}$ & 0.14 & $\begin{array}{c}0.1 \\
1\end{array}$ & $\begin{array}{c}0.0 \\
2\end{array}$ & $\begin{array}{c}64 . \\
3\end{array}$ & $\begin{array}{c}66 . \\
2\end{array}$ & 0.76 \\
\hline 8 & & 30 & $\begin{array}{c}73 . \\
2\end{array}$ & 16.4 & $\begin{array}{c}1.3 \\
4\end{array}$ & 4.00 & 0.02 & 1.14 & $\begin{array}{c}1.3 \\
2\end{array}$ & 1.53 & $\begin{array}{c}2.0 \\
0\end{array}$ & $\begin{array}{c}0.1 \\
1\end{array}$ & $\begin{array}{c}69 . \\
9\end{array}$ & $\begin{array}{c}74 . \\
3\end{array}$ & 1.30 \\
\hline 9 & KOLLAM & 50 & $\begin{array}{c}96 . \\
0\end{array}$ & 2.8 & $\begin{array}{c}0.6 \\
7\end{array}$ & 1.19 & 0.01 & 0.19 & $\begin{array}{c}0.3 \\
5\end{array}$ & 0.34 & $\begin{array}{c}0.4 \\
5\end{array}$ & $\begin{array}{c}0.0 \\
2\end{array}$ & $\begin{array}{c}62 . \\
3\end{array}$ & $\begin{array}{c}65 . \\
8\end{array}$ & 1.33 \\
\hline 11 & & 100 & $\begin{array}{c}77 . \\
6\end{array}$ & 8.2 & $\begin{array}{c}1.2 \\
8\end{array}$ & 3.23 & 0.02 & 0.61 & $\begin{array}{c}0.6 \\
4\end{array}$ & 0.73 & $\begin{array}{c}1.3 \\
3\end{array}$ & $\begin{array}{c}0.0 \\
9\end{array}$ & $\begin{array}{c}68 . \\
3\end{array}$ & $\begin{array}{c}74 . \\
1\end{array}$ & 1.82 \\
\hline 13 & & 30 & $\begin{array}{c}92 . \\
1\end{array}$ & 4.6 & $\begin{array}{c}0.5 \\
9\end{array}$ & 1.47 & 0.02 & 0.33 & $\begin{array}{c}0.7 \\
7\end{array}$ & 0.90 & $\begin{array}{c}1.3 \\
2\end{array}$ & $\begin{array}{c}0.0 \\
2\end{array}$ & $\begin{array}{c}51 . \\
4\end{array}$ & $\begin{array}{c}52 . \\
1\end{array}$ & 1.47 \\
\hline 15 & $\mathrm{KOCHI}$ & 100 & $\begin{array}{c}70 . \\
4\end{array}$ & 12.1 & $\begin{array}{c}1.4 \\
6\end{array}$ & 4.10 & 0.03 & 1.12 & $\begin{array}{c}1.1 \\
9\end{array}$ & 1.41 & $\begin{array}{c}2.2 \\
4\end{array}$ & $\begin{array}{c}0.1 \\
0\end{array}$ & $\begin{array}{c}63 . \\
6\end{array}$ & $\begin{array}{c}68 . \\
3\end{array}$ & 1.59 \\
\hline 16 & & 200 & $\begin{array}{c}69 . \\
1\end{array}$ & 11.4 & $\begin{array}{c}1.2 \\
4\end{array}$ & 6.28 & 0.03 & 1.51 & $\begin{array}{c}1.0 \\
1\end{array}$ & 1.24 & $\begin{array}{c}2.0 \\
3\end{array}$ & $\begin{array}{c}0.1 \\
7\end{array}$ & $\begin{array}{c}65 . \\
1\end{array}$ & $\begin{array}{c}70 . \\
2\end{array}$ & 1.63 \\
\hline 17 & & 30 & $\begin{array}{c}54 . \\
7\end{array}$ & 19.3 & $\begin{array}{c}1.1 \\
8\end{array}$ & 6.62 & 0.02 & 1.58 & $\begin{array}{c}0.3 \\
8\end{array}$ & 0.52 & $\begin{array}{c}1.4 \\
7\end{array}$ & $\begin{array}{c}0.1 \\
5\end{array}$ & $\begin{array}{c}86 . \\
0\end{array}$ & $\begin{array}{c}92 . \\
0\end{array}$ & 2.82 \\
\hline 19 & & 100 & $\begin{array}{c}92 . \\
4\end{array}$ & 4.4 & $\begin{array}{c}0.7 \\
3\end{array}$ & 2.00 & 0.01 & 0.45 & $\begin{array}{c}0.4 \\
4\end{array}$ & 0.48 & $\begin{array}{c}0.5 \\
0\end{array}$ & $\begin{array}{c}0.0 \\
5\end{array}$ & $\begin{array}{c}67 . \\
3\end{array}$ & $\begin{array}{c}70 . \\
8\end{array}$ & 1.05 \\
\hline 25 & & 200 & $\begin{array}{c}52 . \\
4\end{array}$ & 20.6 & $\begin{array}{c}1.2 \\
0\end{array}$ & 7.14 & 0.02 & 1.46 & $\begin{array}{c}0.3 \\
1\end{array}$ & 0.45 & $\begin{array}{c}1.3 \\
7\end{array}$ & $\begin{array}{c}0.1 \\
6\end{array}$ & $\begin{array}{c}88 . \\
1\end{array}$ & $\begin{array}{c}93 . \\
7\end{array}$ & 3.06 \\
\hline 24 & KANNUR & 50 & $\begin{array}{c}81 . \\
9\end{array}$ & 8.5 & $\begin{array}{c}0.9 \\
2\end{array}$ & 2.90 & 0.02 & 0.73 & $\begin{array}{c}0.5 \\
7\end{array}$ & 0.76 & $\begin{array}{c}1.0 \\
4\end{array}$ & $\begin{array}{c}0.0 \\
6\end{array}$ & $\begin{array}{c}71 . \\
3\end{array}$ & $\begin{array}{c}76 . \\
3\end{array}$ & 1.37 \\
\hline 21 & & 30 & $\begin{array}{c}51 . \\
6\end{array}$ & 12.0 & $\begin{array}{c}1.0 \\
9\end{array}$ & $\begin{array}{c}15.6 \\
9\end{array}$ & 0.03 & 2.53 & $\begin{array}{c}0.6 \\
6\end{array}$ & 0.66 & $\begin{array}{c}1.3 \\
9\end{array}$ & $\begin{array}{c}0.4 \\
8\end{array}$ & $\begin{array}{c}76 . \\
1\end{array}$ & $\begin{array}{c}82 . \\
2\end{array}$ & 2.11 \\
\hline
\end{tabular}




\begin{tabular}{|c|c|c|c|c|c|c|c|c|c|c|c|c|c|c|c|}
\hline 26 & & 30 & $\begin{array}{c}53 . \\
6\end{array}$ & 20.2 & $\begin{array}{c}1.2 \\
0\end{array}$ & 7.12 & 0.02 & 1.56 & $\begin{array}{c}0.3 \\
1\end{array}$ & 0.48 & $\begin{array}{c}1.5 \\
5\end{array}$ & $\begin{array}{c}0.1 \\
4\end{array}$ & $\begin{array}{c}87 . \\
0\end{array}$ & $\begin{array}{c}93 . \\
2\end{array}$ & 3.22 \\
\hline 29 & & 200 & $\begin{array}{c}89 . \\
1\end{array}$ & 4.9 & $\begin{array}{c}0.8 \\
2\end{array}$ & 2.46 & 0.02 & 0.49 & $\begin{array}{c}0.3 \\
3\end{array}$ & 0.37 & $\begin{array}{c}0.7 \\
1\end{array}$ & $\begin{array}{c}0.0 \\
7\end{array}$ & $\begin{array}{c}71 . \\
0\end{array}$ & $\begin{array}{c}77 . \\
1\end{array}$ & 1.92 \\
\hline 32 & BHAT & 70 & $\begin{array}{c}92 . \\
8\end{array}$ & 2.8 & $\begin{array}{c}1.0 \\
5\end{array}$ & 2.57 & 0.03 & 0.20 & $\begin{array}{c}0.3 \\
2\end{array}$ & 0.57 & $\begin{array}{c}0.6 \\
1\end{array}$ & $\begin{array}{c}0.0 \\
5\end{array}$ & $\begin{array}{c}55 . \\
8\end{array}$ & $\begin{array}{c}58 . \\
0\end{array}$ & 1.06 \\
\hline 35 & & 30 & $\begin{array}{c}51 . \\
7\end{array}$ & 18.1 & $\begin{array}{c}1.3 \\
7\end{array}$ & $\begin{array}{c}11.6 \\
9\end{array}$ & 0.06 & 1.66 & $\begin{array}{c}0.4 \\
6\end{array}$ & 0.47 & $\begin{array}{c}1.5 \\
0\end{array}$ & $\begin{array}{c}0.1 \\
8\end{array}$ & $\begin{array}{c}84 . \\
9\end{array}$ & $\begin{array}{c}91 . \\
1\end{array}$ & 3.22 \\
\hline 36 & & 50 & $\begin{array}{c}56 . \\
4\end{array}$ & 16.6 & $\begin{array}{c}1.3 \\
2\end{array}$ & 8.18 & 0.03 & 1.99 & $\begin{array}{c}0.5 \\
4\end{array}$ & 0.59 & $\begin{array}{c}1.6 \\
1\end{array}$ & $\begin{array}{c}0.1 \\
4\end{array}$ & $\begin{array}{c}81 . \\
8\end{array}$ & $\begin{array}{c}88 . \\
4\end{array}$ & 2.73 \\
\hline $\begin{array}{c}\text { Averag } \\
\text { e }\end{array}$ & & & $\begin{array}{c}76 . \\
1\end{array}$ & 9.7 & $\begin{array}{c}1.0 \\
5\end{array}$ & 5.02 & 0.02 & $\begin{array}{c}0.9 \\
6\end{array}$ & $\begin{array}{c}0.5 \\
4\end{array}$ & 0.64 & $\begin{array}{c}1.1 \\
3\end{array}$ & $\begin{array}{c}0.1 \\
3\end{array}$ & $\begin{array}{c}70 . \\
7\end{array}$ & $\begin{array}{c}75 . \\
3\end{array}$ & 1.87 \\
\hline 40 & RAT & 30 & $\begin{array}{c}49 . \\
4\end{array}$ & 18.9 & $\begin{array}{c}2.0 \\
7\end{array}$ & $\begin{array}{c}13.1 \\
0\end{array}$ & 0.05 & 2.12 & $\begin{array}{c}0.7 \\
8\end{array}$ & 0.44 & $\begin{array}{c}1.2 \\
5\end{array}$ & $\begin{array}{c}0.1 \\
9\end{array}$ & $\begin{array}{c}84 . \\
4\end{array}$ & $\begin{array}{c}89 . \\
1\end{array}$ & 2.86 \\
\hline 45 & MUM & 30 & $\begin{array}{c}51 . \\
8\end{array}$ & 17.9 & $\begin{array}{c}1.8 \\
6\end{array}$ & $\begin{array}{c}12.7 \\
8\end{array}$ & 0.05 & 2.47 & $\begin{array}{c}0.7 \\
1\end{array}$ & 0.50 & $\begin{array}{c}1.5 \\
0\end{array}$ & $\begin{array}{c}0.1 \\
5\end{array}$ & $\begin{array}{c}82 . \\
7\end{array}$ & $\begin{array}{c}88 . \\
5\end{array}$ & 3.00 \\
\hline 54 & VER & 30 & $\begin{array}{c}58 . \\
3\end{array}$ & 15.2 & $\begin{array}{c}1.9 \\
4\end{array}$ & $\begin{array}{c}10.8 \\
0\end{array}$ & 0.06 & 2.46 & $\begin{array}{c}1.8 \\
5\end{array}$ & 1.23 & $\begin{array}{c}1.6 \\
3\end{array}$ & $\begin{array}{c}0.0 \\
8\end{array}$ & $\begin{array}{c}68 . \\
0\end{array}$ & $\begin{array}{c}71 . \\
4\end{array}$ & 1.32 \\
\hline 58 & & 200 & $\begin{array}{c}57 . \\
4\end{array}$ & 16.1 & $\begin{array}{c}1.4 \\
8\end{array}$ & 9.67 & 0.05 & 2.93 & $\begin{array}{c}1.5 \\
2\end{array}$ & 1.12 & $\begin{array}{c}2.0 \\
6\end{array}$ & $\begin{array}{c}0.0 \\
8\end{array}$ & $\begin{array}{c}70 . \\
2\end{array}$ & $\begin{array}{c}75 . \\
1\end{array}$ & 1.83 \\
\hline 55 & & 30 & $\begin{array}{c}54 . \\
9\end{array}$ & 15.6 & $\begin{array}{c}1.6 \\
2\end{array}$ & $\begin{array}{c}10.4 \\
7\end{array}$ & 0.05 & 2.70 & $\begin{array}{c}1.1 \\
2\end{array}$ & 0.90 & $\begin{array}{c}1.8 \\
9\end{array}$ & $\begin{array}{c}0.1 \\
5\end{array}$ & $\begin{array}{c}73 . \\
7\end{array}$ & $\begin{array}{c}79 . \\
4\end{array}$ & 2.11 \\
\hline 60 & DWA & 50 & $\begin{array}{c}58 . \\
7\end{array}$ & 18.7 & $\begin{array}{c}1.0 \\
1\end{array}$ & 7.73 & 0.04 & 3.02 & $\begin{array}{c}0.5 \\
9\end{array}$ & 1.00 & $\begin{array}{c}3.3 \\
6\end{array}$ & $\begin{array}{c}0.0 \\
7\end{array}$ & $\begin{array}{c}74 . \\
6\end{array}$ & $\begin{array}{c}84 . \\
7\end{array}$ & 3.37 \\
\hline $\begin{array}{c}\text { Averag } \\
\text { e }\end{array}$ & & & $\begin{array}{c}55 . \\
3\end{array}$ & 17.0 & $\begin{array}{c}1.6 \\
1\end{array}$ & $\begin{array}{c}10.3 \\
9\end{array}$ & 0.05 & $\begin{array}{c}2.5 \\
3\end{array}$ & $\begin{array}{c}1.0 \\
2\end{array}$ & 0.83 & $\begin{array}{c}1.9 \\
0\end{array}$ & $\begin{array}{c}0.1 \\
2\end{array}$ & $\begin{array}{c}76 . \\
5\end{array}$ & $\begin{array}{c}82 . \\
4\end{array}$ & 2.46 \\
\hline
\end{tabular}


Table 4. Trace and rare-earth element geochemical data (ppm)

\begin{tabular}{|c|c|c|c|c|c|c|c|c|c|c|c|c|c|c|c|c|c|c|c|c|c|}
\hline $\begin{array}{c}\text { St.N } \\
0\end{array}$ & Stations & $\begin{array}{c}\text { Depth } \\
\text { (m) }\end{array}$ & La & $\mathrm{Ce}$ & $\mathrm{Pr}$ & Nd & $\begin{array}{l}S \\
m\end{array}$ & Eu & $\begin{array}{l}\mathbf{G} \\
\mathbf{d}\end{array}$ & Tb & $\begin{array}{l}D \\
y\end{array}$ & $\begin{array}{l}\mathrm{H} \\
\mathrm{O}\end{array}$ & $\mathrm{Er}$ & $\mathrm{Tm}$ & $\mathrm{Yb}$ & Lu & $\begin{array}{c}\sum R E \\
E\end{array}$ & Sc & Ga & $\mathbf{R b}$ & Th \\
\hline 1 & \multirow{3}{*}{$\begin{array}{l}\text { CAPE } \\
\text { COM }\end{array}$} & 30 & $\begin{array}{c}20 . \\
9\end{array}$ & $\begin{array}{c}46 . \\
0\end{array}$ & $\begin{array}{l}5 . \\
0\end{array}$ & $\begin{array}{c}20 . \\
7\end{array}$ & $\begin{array}{l}3 . \\
7\end{array}$ & $\begin{array}{c}0 . \\
5\end{array}$ & $\begin{array}{l}2 . \\
8\end{array}$ & $\begin{array}{l}0 . \\
4\end{array}$ & $\begin{array}{l}2 . \\
1\end{array}$ & $\begin{array}{c}0 . \\
4\end{array}$ & $\begin{array}{l}1 . \\
2\end{array}$ & $\begin{array}{c}0.1 \\
7\end{array}$ & $\begin{array}{c}0.9 \\
6\end{array}$ & $\begin{array}{c}0.1 \\
5\end{array}$ & 105 & 2.4 & 1.7 & 5.0 & 9.5 \\
\hline 3 & & 100 & 7.6 & $\begin{array}{c}11 . \\
8\end{array}$ & $\begin{array}{c}1 . \\
6\end{array}$ & 6.5 & $\begin{array}{l}1 . \\
4\end{array}$ & $\begin{array}{l}0 . \\
4\end{array}$ & $\begin{array}{l}1 . \\
3\end{array}$ & $\begin{array}{l}0 . \\
2\end{array}$ & $\begin{array}{l}1 . \\
5\end{array}$ & $\begin{array}{l}0 . \\
3\end{array}$ & $\begin{array}{l}0 . \\
9\end{array}$ & $\begin{array}{c}0.1 \\
4\end{array}$ & $\begin{array}{c}0.7 \\
5\end{array}$ & $\begin{array}{c}0.1 \\
2\end{array}$ & 34 & 1.2 & 0.9 & 2.8 & 1.6 \\
\hline 4 & & 200 & 8.9 & $\begin{array}{c}13 . \\
8\end{array}$ & $\begin{array}{l}1 . \\
9\end{array}$ & 7.5 & $\begin{array}{l}1 . \\
5\end{array}$ & $\begin{array}{l}0 . \\
4\end{array}$ & $\begin{array}{l}1 . \\
3\end{array}$ & $\begin{array}{l}0 . \\
3\end{array}$ & $\begin{array}{l}1 . \\
5\end{array}$ & $\begin{array}{l}0 . \\
4\end{array}$ & $\begin{array}{l}0 . \\
9\end{array}$ & $\begin{array}{c}0.1 \\
4\end{array}$ & $\begin{array}{c}0.7 \\
7\end{array}$ & $\begin{array}{c}0.1 \\
3\end{array}$ & 39 & 2.4 & 2.0 & 8.0 & 2.3 \\
\hline 7 & \multirow{2}{*}{ TVM } & 30 & 5.3 & $\begin{array}{c}10 . \\
4\end{array}$ & $\begin{array}{l}1 . \\
1\end{array}$ & 4.3 & $\begin{array}{l}0 . \\
9\end{array}$ & $\begin{array}{l}0 . \\
2\end{array}$ & $\begin{array}{l}0 . \\
7\end{array}$ & $\begin{array}{c}0 . \\
1\end{array}$ & $\begin{array}{l}0 . \\
7\end{array}$ & $\begin{array}{c}0 . \\
1\end{array}$ & $\begin{array}{c}0 . \\
4\end{array}$ & $\begin{array}{c}0.0 \\
7\end{array}$ & $\begin{array}{c}0.4 \\
2\end{array}$ & $\begin{array}{c}0.0 \\
7\end{array}$ & 25 & 6.3 & 1.9 & 5.1 & 2.6 \\
\hline 5 & & 125 & 4.6 & 7.6 & $\begin{array}{l}1 . \\
0\end{array}$ & 3.9 & $\begin{array}{l}0 . \\
8\end{array}$ & $\begin{array}{l}0 . \\
2\end{array}$ & $\begin{array}{l}0 . \\
8\end{array}$ & $\begin{array}{c}0 . \\
1\end{array}$ & $\begin{array}{l}0 . \\
9\end{array}$ & $\begin{array}{l}0 . \\
2\end{array}$ & $\begin{array}{l}0 . \\
5\end{array}$ & $\begin{array}{c}0.0 \\
8\end{array}$ & $\begin{array}{c}0.4 \\
5\end{array}$ & $\begin{array}{c}0.0 \\
7\end{array}$ & 21 & 0.9 & 0.7 & 1.4 & 1.0 \\
\hline 8 & \multirow{3}{*}{ KOLLAM } & 30 & $\begin{array}{c}44 . \\
4\end{array}$ & $\begin{array}{c}85 . \\
4\end{array}$ & $\begin{array}{c}8 . \\
4\end{array}$ & $\begin{array}{c}32 . \\
9\end{array}$ & $\begin{array}{l}6 . \\
0\end{array}$ & $\begin{array}{l}1 . \\
4\end{array}$ & $\begin{array}{l}4 . \\
7\end{array}$ & $\begin{array}{l}0 . \\
7\end{array}$ & $\begin{array}{l}4 . \\
0\end{array}$ & $\begin{array}{l}0 . \\
8\end{array}$ & $\begin{array}{l}2 . \\
3\end{array}$ & $\begin{array}{c}0.3 \\
2\end{array}$ & $\begin{array}{c}1.9 \\
5\end{array}$ & $\begin{array}{c}0.3 \\
1\end{array}$ & 194 & $\begin{array}{c}12 . \\
1\end{array}$ & $\begin{array}{c}12 . \\
7\end{array}$ & $\begin{array}{c}47 . \\
7\end{array}$ & $\begin{array}{c}13 . \\
6\end{array}$ \\
\hline 9 & & 50 & $\begin{array}{c}13 . \\
7\end{array}$ & $\begin{array}{c}25 . \\
7\end{array}$ & $\begin{array}{c}2 . \\
5\end{array}$ & 9.9 & $\begin{array}{l}1 . \\
7\end{array}$ & $\begin{array}{l}0 . \\
3\end{array}$ & $\begin{array}{l}1 . \\
2\end{array}$ & $\begin{array}{l}0 . \\
2\end{array}$ & $\begin{array}{l}1 . \\
0\end{array}$ & $\begin{array}{l}0 . \\
2\end{array}$ & $\begin{array}{l}0 . \\
6\end{array}$ & $\begin{array}{c}0.0 \\
8\end{array}$ & $\begin{array}{c}0.4 \\
6\end{array}$ & $\begin{array}{c}0.0 \\
8\end{array}$ & 58 & 6.3 & 3.0 & $\begin{array}{c}11 . \\
3\end{array}$ & 6.3 \\
\hline 11 & & 100 & $\begin{array}{c}24 . \\
2\end{array}$ & $\begin{array}{c}42 . \\
6\end{array}$ & $\begin{array}{l}4 . \\
3\end{array}$ & $\begin{array}{c}16 . \\
1\end{array}$ & $\begin{array}{l}2 . \\
8\end{array}$ & $\begin{array}{l}0 . \\
5\end{array}$ & $\begin{array}{l}2 . \\
3\end{array}$ & $\begin{array}{l}0 . \\
3\end{array}$ & $\begin{array}{l}1 . \\
7\end{array}$ & $\begin{array}{l}0 . \\
3\end{array}$ & $\begin{array}{l}1 . \\
0\end{array}$ & $\begin{array}{c}0.1 \\
3\end{array}$ & $\begin{array}{c}0.7 \\
4\end{array}$ & $\begin{array}{c}0.1 \\
0\end{array}$ & 97 & 5.4 & 2.9 & $\begin{array}{c}11 . \\
1\end{array}$ & 8.6 \\
\hline 13 & \multirow{3}{*}{$\mathrm{KOCHI}$} & 30 & $\begin{array}{c}21 . \\
0\end{array}$ & $\begin{array}{c}35 . \\
4\end{array}$ & $\begin{array}{l}3 . \\
3\end{array}$ & $\begin{array}{c}12 . \\
1\end{array}$ & $\begin{array}{l}1 . \\
9\end{array}$ & $\begin{array}{l}0 . \\
6\end{array}$ & $\begin{array}{l}1 . \\
5\end{array}$ & $\begin{array}{l}0 . \\
2\end{array}$ & $\begin{array}{l}1 . \\
1\end{array}$ & $\begin{array}{l}0 . \\
2\end{array}$ & $\begin{array}{l}0 . \\
7\end{array}$ & $\begin{array}{c}0.0 \\
9\end{array}$ & $\begin{array}{c}0.5 \\
6\end{array}$ & $\begin{array}{c}0.0 \\
9\end{array}$ & 79 & 6.5 & 4.7 & $\begin{array}{c}27 . \\
1\end{array}$ & 8.6 \\
\hline 15 & & 100 & $\begin{array}{c}50 . \\
5\end{array}$ & $\begin{array}{c}85 . \\
2\end{array}$ & $\begin{array}{l}7 . \\
7\end{array}$ & $\begin{array}{c}28 . \\
1\end{array}$ & $\begin{array}{l}4 . \\
3\end{array}$ & $\begin{array}{l}0 . \\
8\end{array}$ & $\begin{array}{l}3 . \\
4\end{array}$ & $\begin{array}{l}0 . \\
5\end{array}$ & $\begin{array}{c}2 . \\
4\end{array}$ & $\begin{array}{l}0 . \\
5\end{array}$ & $\begin{array}{l}1 . \\
3\end{array}$ & $\begin{array}{c}0.1 \\
8\end{array}$ & $\begin{array}{c}1.0 \\
4\end{array}$ & $\begin{array}{c}0.1 \\
7\end{array}$ & 186 & 6.9 & 5.6 & $\begin{array}{c}21 . \\
7\end{array}$ & $\begin{array}{c}14 . \\
7\end{array}$ \\
\hline 16 & & 200 & $\begin{array}{c}40 . \\
2\end{array}$ & $\begin{array}{c}75 . \\
3\end{array}$ & $\begin{array}{l}7 . \\
3\end{array}$ & $\begin{array}{c}28 . \\
9\end{array}$ & $\begin{array}{l}5 . \\
0\end{array}$ & $\begin{array}{l}1 . \\
0\end{array}$ & $\begin{array}{l}3 . \\
8\end{array}$ & $\begin{array}{l}0 . \\
6\end{array}$ & $\begin{array}{l}2 . \\
8\end{array}$ & $\begin{array}{l}0 . \\
5\end{array}$ & $\begin{array}{l}1 . \\
5\end{array}$ & $\begin{array}{c}0.2 \\
0\end{array}$ & $\begin{array}{c}1.1 \\
7\end{array}$ & $\begin{array}{c}0.1 \\
8\end{array}$ & 168 & 8.6 & 6.7 & $\begin{array}{c}23 . \\
7\end{array}$ & $\begin{array}{c}15 . \\
5\end{array}$ \\
\hline 17 & \multirow{2}{*}{ CAL } & 30 & $\begin{array}{c}28 . \\
5\end{array}$ & $\begin{array}{c}61 . \\
1\end{array}$ & $\begin{array}{l}5 . \\
8\end{array}$ & $\begin{array}{c}24 . \\
5\end{array}$ & $\begin{array}{l}4 . \\
8\end{array}$ & $\begin{array}{l}1 . \\
3\end{array}$ & $\begin{array}{l}4 . \\
1\end{array}$ & $\begin{array}{l}0 . \\
7\end{array}$ & $\begin{array}{l}4 . \\
3\end{array}$ & $\begin{array}{c}0 . \\
9\end{array}$ & $\begin{array}{c}2 . \\
5\end{array}$ & $\begin{array}{c}0.3 \\
6\end{array}$ & $\begin{array}{c}2.2 \\
2\end{array}$ & $\begin{array}{c}0.3 \\
1\end{array}$ & 141 & $\begin{array}{c}16 . \\
7\end{array}$ & $\begin{array}{c}15 . \\
7\end{array}$ & $\begin{array}{c}56 . \\
2\end{array}$ & 7.8 \\
\hline 19 & & 100 & $\begin{array}{c}12 . \\
4\end{array}$ & $\begin{array}{c}25 . \\
6\end{array}$ & $\begin{array}{l}2 . \\
7\end{array}$ & $\begin{array}{c}11 . \\
3\end{array}$ & $\begin{array}{l}2 . \\
4\end{array}$ & $\begin{array}{l}0 . \\
6\end{array}$ & $\begin{array}{l}2 . \\
0\end{array}$ & $\begin{array}{l}0 . \\
3\end{array}$ & $\begin{array}{l}2 . \\
0\end{array}$ & $\begin{array}{c}0 . \\
4\end{array}$ & $\begin{array}{l}1 . \\
0\end{array}$ & $\begin{array}{c}0.1 \\
4\end{array}$ & $\begin{array}{c}0.8 \\
2\end{array}$ & $\begin{array}{c}0.1 \\
3\end{array}$ & 62 & 3.6 & 3.3 & $\begin{array}{c}10 . \\
3\end{array}$ & 2.4 \\
\hline 25 & \multirow{2}{*}{ KANNUR } & 30 & $\begin{array}{c}29 . \\
6\end{array}$ & $\begin{array}{c}66 . \\
3\end{array}$ & $\begin{array}{c}6 . \\
1\end{array}$ & $\begin{array}{c}25 . \\
8\end{array}$ & $\begin{array}{l}5 . \\
3\end{array}$ & $\begin{array}{l}1 . \\
3\end{array}$ & $\begin{array}{l}4 . \\
4\end{array}$ & $\begin{array}{l}0 . \\
8\end{array}$ & $\begin{array}{l}4 . \\
5\end{array}$ & $\begin{array}{l}0 . \\
9\end{array}$ & $\begin{array}{l}2 . \\
7\end{array}$ & $\begin{array}{c}0.3 \\
7\end{array}$ & $\begin{array}{c}2.3 \\
0\end{array}$ & $\begin{array}{c}0.3 \\
4\end{array}$ & 151 & $\begin{array}{c}18 . \\
2\end{array}$ & $\begin{array}{c}17 . \\
6\end{array}$ & $\begin{array}{c}56 . \\
5\end{array}$ & 8.7 \\
\hline 21 & & 200 & $\begin{array}{c}13 . \\
3\end{array}$ & $\begin{array}{c}28 . \\
1\end{array}$ & $\begin{array}{c}3 . \\
1\end{array}$ & $\begin{array}{c}13 . \\
2\end{array}$ & $\begin{array}{l}2 . \\
7\end{array}$ & $\begin{array}{l}0 . \\
7\end{array}$ & $\begin{array}{l}2 . \\
3\end{array}$ & $\begin{array}{c}0 . \\
4\end{array}$ & $\begin{array}{c}2 . \\
3\end{array}$ & $\begin{array}{c}0 . \\
5\end{array}$ & $\begin{array}{l}1 . \\
2\end{array}$ & $\begin{array}{c}0.1 \\
9\end{array}$ & $\begin{array}{c}1.0 \\
6\end{array}$ & $\begin{array}{c}0.1 \\
7\end{array}$ & 69 & 5.7 & 5.0 & $\begin{array}{c}18 . \\
6\end{array}$ & 3.7 \\
\hline 26 & MNG & 30 & $\begin{array}{c}28 . \\
4\end{array}$ & $\begin{array}{c}62 . \\
2\end{array}$ & $\begin{array}{l}5 . \\
8\end{array}$ & $\begin{array}{c}23 . \\
8\end{array}$ & $\begin{array}{c}5 . \\
1\end{array}$ & $\begin{array}{l}1 . \\
3\end{array}$ & $\begin{array}{l}4 . \\
2\end{array}$ & $\begin{array}{l}0 . \\
7\end{array}$ & $\begin{array}{l}4 . \\
2\end{array}$ & $\begin{array}{l}0 . \\
9\end{array}$ & $\begin{array}{c}2 . \\
5\end{array}$ & $\begin{array}{c}0.3 \\
6\end{array}$ & $\begin{array}{c}2.2 \\
1\end{array}$ & $\begin{array}{c}0.3 \\
1\end{array}$ & 142 & $\begin{array}{c}17 . \\
9\end{array}$ & $\begin{array}{c}17 . \\
5\end{array}$ & $\begin{array}{c}63 . \\
4\end{array}$ & 8.9 \\
\hline
\end{tabular}




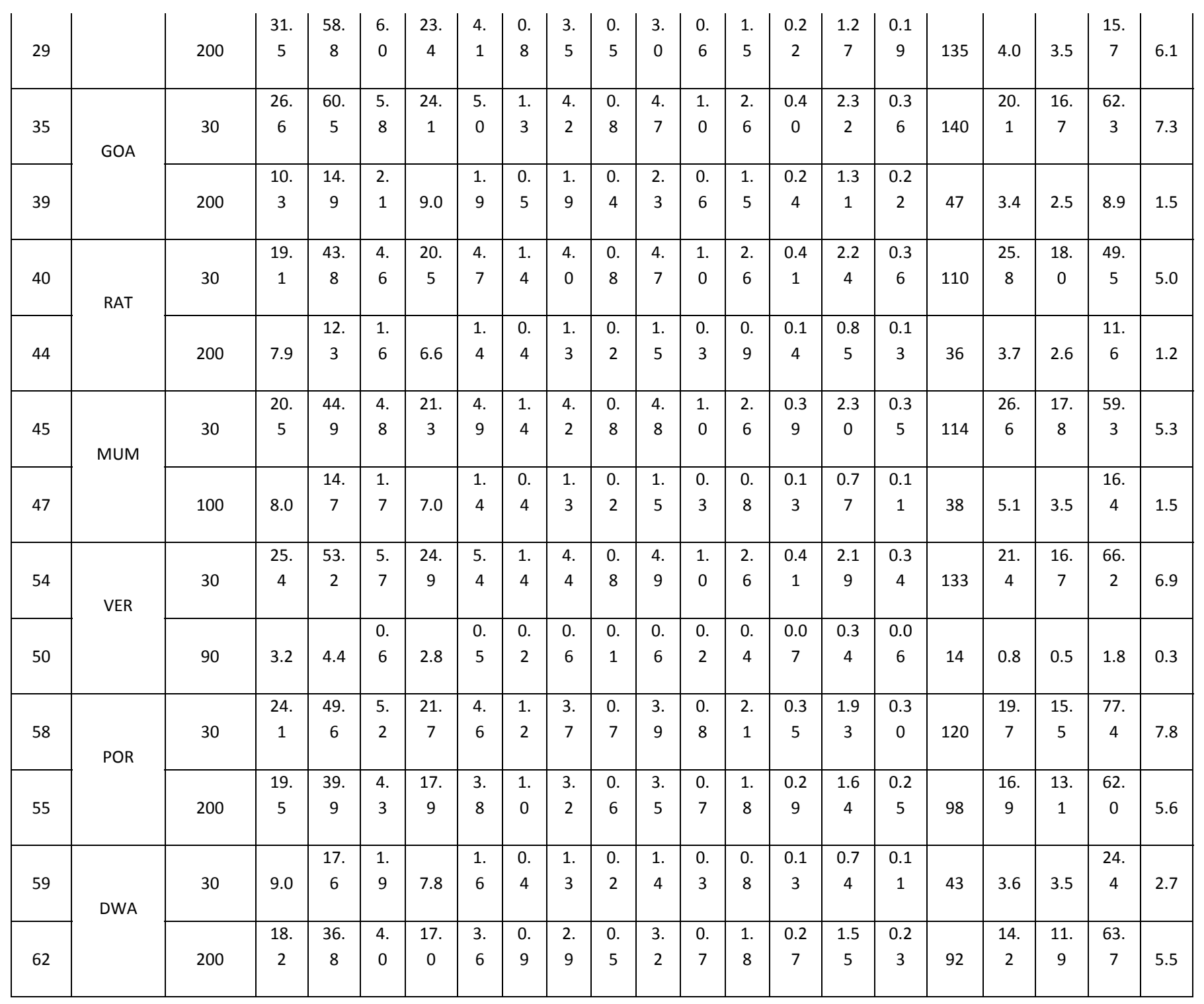


Table 5. Trace element geochemical data (ppm) and fractionation indices (calculated on carbonate-free basis) and elemental ratios used in discussion

\begin{tabular}{|c|c|c|c|c|c|c|c|c|c|c|c|c|c|c|c|c|c|}
\hline $\begin{array}{l}\text { St. } \\
\text { No }\end{array}$ & $\begin{array}{c}\text { Station } \\
\mathrm{s}\end{array}$ & $\begin{array}{c}\text { Depth } \\
\text { (m) }\end{array}$ & $\mathrm{Ba}$ & $\mathrm{Hf}$ & $\mathrm{Ta}$ & $\mathrm{Sr}$ & $Y$ & $\mathrm{Zr}$ & $\mathrm{Nb}$ & $\mathbf{U}$ & $\begin{array}{l}\Sigma R \\
E E\end{array}$ & $\begin{array}{c}\text { Eu } \\
\text { ano }\end{array}$ & $\begin{array}{c}\mathrm{Ce} \\
\text { ano }\end{array}$ & $\begin{array}{c}\text { (La) } \\
\text { n/ } \\
\text { (Yb) } \\
n\end{array}$ & $\begin{array}{c}\text { (Sm) } \\
n / \\
(Y b) \\
n\end{array}$ & $\begin{array}{l}\mathrm{Rb} / \\
\mathrm{Ga}\end{array}$ & $\begin{array}{l}\text { Th/ } \\
\text { Sc }\end{array}$ \\
\hline 1 & & 30 & 60 & $\begin{array}{c}0.2 \\
7\end{array}$ & $\begin{array}{c}0.1 \\
1\end{array}$ & $\begin{array}{l}15 \\
03\end{array}$ & $\begin{array}{c}14 . \\
0\end{array}$ & 9 & $\begin{array}{c}4.6 \\
8\end{array}$ & $\begin{array}{c}1.1 \\
4\end{array}$ & $\begin{array}{c}44 \\
3\end{array}$ & 0.8 & 1 & 1.6 & 1.8 & 3 & $\begin{array}{c}3.8 \\
7\end{array}$ \\
\hline 3 & $\begin{array}{l}\text { CAPE } \\
\text { COM }\end{array}$ & 100 & 37 & $\begin{array}{c}0.2 \\
6\end{array}$ & $\begin{array}{c}0.0 \\
2\end{array}$ & $\begin{array}{l}19 \\
57\end{array}$ & $\begin{array}{c}13 . \\
0\end{array}$ & 9 & $\begin{array}{c}0.7 \\
1\end{array}$ & $\begin{array}{c}2.8 \\
4\end{array}$ & $\begin{array}{c}24 \\
9\end{array}$ & 1.2 & 0.8 & 0.7 & 2.5 & 3.3 & $\begin{array}{c}1.3 \\
9\end{array}$ \\
\hline 4 & & 200 & 48 & $\begin{array}{c}0.3 \\
1\end{array}$ & $\begin{array}{c}0.0 \\
5\end{array}$ & $\begin{array}{l}12 \\
46\end{array}$ & $\begin{array}{c}12 . \\
7\end{array}$ & 10 & $\begin{array}{c}1.0 \\
5\end{array}$ & $\begin{array}{c}3.7 \\
7\end{array}$ & $\begin{array}{c}20 \\
2\end{array}$ & 1.2 & 0.8 & 0.9 & 1.6 & 4 & $\begin{array}{c}0.9 \\
3\end{array}$ \\
\hline 7 & TVMM & 30 & 65 & $\begin{array}{c}1.0 \\
0\end{array}$ & $\begin{array}{c}0.1 \\
7\end{array}$ & $\begin{array}{c}10 \\
5\end{array}$ & 4.2 & 35 & $\begin{array}{c}4.5 \\
2\end{array}$ & $\begin{array}{c}0.4 \\
8\end{array}$ & 25 & 1.1 & 1 & 0.9 & 0.2 & 2.7 & $\begin{array}{c}0.4 \\
1\end{array}$ \\
\hline 5 & & 125 & 21 & $\begin{array}{c}0.1 \\
2\end{array}$ & $\begin{array}{c}0.0 \\
1\end{array}$ & $\begin{array}{l}20 \\
56\end{array}$ & 7.5 & 4 & $\begin{array}{c}0.4 \\
7\end{array}$ & $\begin{array}{c}1.8 \\
1\end{array}$ & $\begin{array}{c}33 \\
7\end{array}$ & 1.3 & 0.8 & 0.8 & 3.1 & 2.2 & $\begin{array}{c}1.0 \\
6\end{array}$ \\
\hline 8 & & 30 & $\begin{array}{c}55 \\
1\end{array}$ & $\begin{array}{c}2.9 \\
0\end{array}$ & $\begin{array}{c}0.4 \\
1\end{array}$ & $\begin{array}{c}42 \\
0\end{array}$ & $\begin{array}{c}25 . \\
4\end{array}$ & $\begin{array}{c}10 \\
9\end{array}$ & $\begin{array}{c}9.5 \\
5\end{array}$ & $\begin{array}{c}2.3 \\
2\end{array}$ & $\begin{array}{c}20 \\
7\end{array}$ & 1.2 & 1 & 1.7 & 0.7 & 3.8 & $\begin{array}{c}1.1 \\
3\end{array}$ \\
\hline 9 & $\begin{array}{c}\text { KOLLA } \\
\text { M }\end{array}$ & 50 & $\begin{array}{c}20 \\
4\end{array}$ & $\begin{array}{c}0.9 \\
3\end{array}$ & $\begin{array}{c}0.2 \\
0\end{array}$ & $\begin{array}{c}22 \\
3\end{array}$ & 5.8 & 37 & $\begin{array}{c}6.4 \\
0\end{array}$ & $\begin{array}{c}0.8 \\
3\end{array}$ & 62 & 1.1 & 1 & 2.2 & 0.2 & 3.8 & $\begin{array}{c}0.9 \\
9\end{array}$ \\
\hline 11 & & 100 & $\begin{array}{c}14 \\
7\end{array}$ & $\begin{array}{c}0.6 \\
9\end{array}$ & $\begin{array}{c}0.1 \\
0\end{array}$ & $\begin{array}{l}18 \\
93\end{array}$ & $\begin{array}{c}12 . \\
0\end{array}$ & 28 & $\begin{array}{c}3.3 \\
6\end{array}$ & $\begin{array}{c}2.4 \\
7\end{array}$ & $\begin{array}{c}37 \\
7\end{array}$ & 0.9 & 1 & 2.4 & 0.8 & 3.9 & $\begin{array}{c}1.5 \\
9\end{array}$ \\
\hline 13 & & 30 & $\begin{array}{c}55 \\
3\end{array}$ & $\begin{array}{c}1.4 \\
0\end{array}$ & $\begin{array}{c}0.4 \\
1\end{array}$ & $\begin{array}{c}27 \\
9\end{array}$ & 6.9 & 57 & $\begin{array}{c}6.1 \\
2\end{array}$ & $\begin{array}{c}0.5 \\
9\end{array}$ & 81 & 1.6 & 1 & 2.8 & 0.1 & 5.8 & $\begin{array}{c}1.3 \\
3\end{array}$ \\
\hline 15 & $\mathrm{KOCHI}$ & 100 & $\begin{array}{c}30 \\
0\end{array}$ & $\begin{array}{c}1.4 \\
4\end{array}$ & $\begin{array}{c}0.3 \\
2\end{array}$ & $\begin{array}{l}13 \\
40\end{array}$ & $\begin{array}{c}15 . \\
7\end{array}$ & 60 & $\begin{array}{c}5.0 \\
5\end{array}$ & $\begin{array}{c}2.2 \\
2\end{array}$ & $\begin{array}{c}47 \\
3\end{array}$ & 1 & 1 & 3.6 & 0.5 & 3.9 & $\begin{array}{c}2.1 \\
2\end{array}$ \\
\hline 16 & & 200 & $\begin{array}{c}32 \\
6\end{array}$ & $\begin{array}{c}2.0 \\
5\end{array}$ & $\begin{array}{c}0.3 \\
8\end{array}$ & $\begin{array}{c}97 \\
0\end{array}$ & $\begin{array}{c}15 . \\
8\end{array}$ & 73 & $\begin{array}{c}4.6 \\
6\end{array}$ & $\begin{array}{c}2.2 \\
3\end{array}$ & $\begin{array}{c}34 \\
9\end{array}$ & 1 & 1 & 2.5 & 0.7 & 3.6 & $\begin{array}{c}1.8 \\
1\end{array}$ \\
\hline 17 & CA & 30 & $\begin{array}{c}17 \\
7\end{array}$ & $\begin{array}{c}2.2 \\
9\end{array}$ & $\begin{array}{c}0.7 \\
8\end{array}$ & $\begin{array}{c}20 \\
9\end{array}$ & $\begin{array}{c}26 . \\
0\end{array}$ & 82 & $\begin{array}{c}8.0 \\
6\end{array}$ & $\begin{array}{c}2.6 \\
1\end{array}$ & $\begin{array}{c}14 \\
6\end{array}$ & 1.3 & 1.1 & 0.9 & 1 & 3.6 & $\begin{array}{c}0.4 \\
7\end{array}$ \\
\hline 19 & & 100 & 91 & $\begin{array}{c}0.8 \\
8\end{array}$ & $\begin{array}{c}0.1 \\
1\end{array}$ & $\begin{array}{c}53 \\
9\end{array}$ & $\begin{array}{c}11 . \\
5\end{array}$ & 35 & $\begin{array}{c}2.9 \\
0\end{array}$ & $\begin{array}{c}1.0 \\
8\end{array}$ & 87 & 1.4 & 1 & 1.1 & 0.5 & 3.1 & $\begin{array}{c}0.6 \\
6\end{array}$ \\
\hline 25 & KANNU & 30 & 16 & 2.5 & 0.7 & 18 & 27. & 92 & 8.7 & 2.6 & 15 & 1.3 & 1.1 & 1 & 1 & 3.2 & 0.4 \\
\hline
\end{tabular}




\begin{tabular}{|c|c|c|c|c|c|c|c|c|c|c|c|c|c|c|c|c|c|}
\hline & $R$ & & 3 & 8 & 6 & 7 & 4 & & 8 & 8 & 1 & & & & & & 8 \\
\hline 21 & & 200 & 64 & $\begin{array}{c}1.0 \\
7\end{array}$ & $\begin{array}{c}0.1 \\
4\end{array}$ & $\begin{array}{l}11 \\
92\end{array}$ & $\begin{array}{c}13 . \\
9\end{array}$ & 39 & $\begin{array}{c}2.6 \\
8\end{array}$ & $\begin{array}{c}1.9 \\
3\end{array}$ & $\begin{array}{c}18 \\
9\end{array}$ & 1.3 & 1 & 0.9 & 1.4 & 3.7 & $\begin{array}{c}0.6 \\
5\end{array}$ \\
\hline 26 & & 30 & $\begin{array}{c}17 \\
4\end{array}$ & $\begin{array}{c}2.6 \\
6\end{array}$ & $\begin{array}{c}0.7 \\
6\end{array}$ & $\begin{array}{c}20 \\
1\end{array}$ & $\begin{array}{c}25 . \\
5\end{array}$ & 95 & $\begin{array}{c}8.8 \\
4\end{array}$ & $\begin{array}{c}2.6 \\
3\end{array}$ & $\begin{array}{c}15 \\
0\end{array}$ & 1.3 & 1.1 & 0.9 & 1 & 3.6 & $\begin{array}{c}0.5 \\
0\end{array}$ \\
\hline 29 & & 200 & 82 & $\begin{array}{c}2.8 \\
3\end{array}$ & $\begin{array}{c}0.1 \\
1\end{array}$ & $\begin{array}{c}84 \\
6\end{array}$ & $\begin{array}{c}17 \\
2\end{array}$ & $\begin{array}{c}10 \\
3\end{array}$ & $\begin{array}{c}2.7 \\
0\end{array}$ & $\begin{array}{c}1.4 \\
5\end{array}$ & $\begin{array}{c}24 \\
5\end{array}$ & 1 & 1 & 1.8 & 0.7 & 4.5 & $\begin{array}{c}1.5 \\
2\end{array}$ \\
\hline 35 & & 30 & $\begin{array}{c}16 \\
1\end{array}$ & $\begin{array}{c}3.1 \\
7\end{array}$ & $\begin{array}{c}0.4 \\
9\end{array}$ & $\begin{array}{c}17 \\
0\end{array}$ & $\begin{array}{c}28 . \\
2\end{array}$ & $\begin{array}{c}12 \\
2\end{array}$ & $\begin{array}{c}8.5 \\
5\end{array}$ & $\begin{array}{c}2.5 \\
0\end{array}$ & $\begin{array}{c}14 \\
3\end{array}$ & 1.4 & 1.1 & 0.8 & 1.1 & 3.7 & $\begin{array}{c}0.3 \\
6\end{array}$ \\
\hline 39 & & 200 & 47 & $\begin{array}{c}0.4 \\
1\end{array}$ & $\begin{array}{c}0.0 \\
6\end{array}$ & $\begin{array}{l}18 \\
42\end{array}$ & $\begin{array}{c}23 . \\
0\end{array}$ & 15 & $\begin{array}{c}1.4 \\
3\end{array}$ & $\begin{array}{c}5.0 \\
0\end{array}$ & $\begin{array}{c}17 \\
4\end{array}$ & 1.3 & 0.7 & 0.6 & 2.2 & 3.6 & $\begin{array}{c}0.4 \\
4\end{array}$ \\
\hline 40 & & 30 & $\begin{array}{c}11 \\
7\end{array}$ & $\begin{array}{c}3.9 \\
1\end{array}$ & $\begin{array}{c}0.5 \\
5\end{array}$ & $\begin{array}{c}20 \\
3\end{array}$ & $\begin{array}{c}28 . \\
5\end{array}$ & $\begin{array}{c}15 \\
2\end{array}$ & $\begin{array}{c}8.6 \\
2\end{array}$ & $\begin{array}{c}1.9 \\
2\end{array}$ & $\begin{array}{c}11 \\
8\end{array}$ & 1.5 & 1.1 & 0.6 & 15 & 27 & $\begin{array}{c}0.2 \\
0\end{array}$ \\
\hline 44 & & 200 & 52 & $\begin{array}{c}0.5 \\
8\end{array}$ & $\begin{array}{c}0.0 \\
8\end{array}$ & $\begin{array}{l}26 \\
60\end{array}$ & $\begin{array}{c}14 . \\
9\end{array}$ & 22 & $\begin{array}{c}1.7 \\
1\end{array}$ & $\begin{array}{c}4.5 \\
5\end{array}$ & $\begin{array}{c}11 \\
7\end{array}$ & 1.3 & 0.8 & 0.7 & 1.2 & 4.5 & $\begin{array}{c}0.3 \\
4\end{array}$ \\
\hline 45 & & 30 & $\begin{array}{c}12 \\
2\end{array}$ & $\begin{array}{c}3.9 \\
7\end{array}$ & $\begin{array}{c}0.5 \\
3\end{array}$ & $\begin{array}{c}35 \\
6\end{array}$ & $\begin{array}{c}29 . \\
2\end{array}$ & $\begin{array}{c}15 \\
7\end{array}$ & $\begin{array}{c}8.5 \\
8\end{array}$ & $\begin{array}{c}1.5 \\
2\end{array}$ & 12 & 1.4 & 1 & 07 & 14 & 33 & 0.2 \\
\hline 47 & & 100 & 54 & $\begin{array}{c}0.6 \\
8\end{array}$ & $\begin{array}{c}0.0 \\
7\end{array}$ & $\begin{array}{l}48 \\
03\end{array}$ & $\begin{array}{c}12 . \\
1\end{array}$ & 27 & $\begin{array}{c}1.9 \\
2\end{array}$ & $\begin{array}{c}3.3 \\
4\end{array}$ & $\begin{array}{c}15 \\
2\end{array}$ & 1.4 & 0.9 & 0.8 & 1.3 & 4.7 & $\begin{array}{c}0.2 \\
9\end{array}$ \\
\hline 54 & & 30 & $\begin{array}{c}18 \\
8\end{array}$ & $\begin{array}{c}3.6 \\
7\end{array}$ & $\begin{array}{c}0.5 \\
9\end{array}$ & $\begin{array}{c}20 \\
7\end{array}$ & $\begin{array}{c}28 . \\
9\end{array}$ & $\begin{array}{c}15 \\
1\end{array}$ & $\begin{array}{l}10 . \\
24\end{array}$ & $\begin{array}{c}1.2 \\
2\end{array}$ & $\begin{array}{c}15 \\
1\end{array}$ & 1.4 & 1 & 0.9 & 13 & 4 & $\begin{array}{c}0.3 \\
2\end{array}$ \\
\hline 50 & & 90 & 25 & $\begin{array}{c}0.0 \\
9\end{array}$ & $\begin{array}{c}0.0 \\
1\end{array}$ & $\begin{array}{l}77 \\
05\end{array}$ & 7.3 & 4 & $\begin{array}{c}0.4 \\
8\end{array}$ & $\begin{array}{c}3.6 \\
9\end{array}$ & $\begin{array}{c}20 \\
2\end{array}$ & 1.4 & 0.7 & 0.7 & 2 & 3.6 & $\begin{array}{c}0.4 \\
4\end{array}$ \\
\hline 58 & & 30 & $\begin{array}{c}20 \\
6\end{array}$ & $\begin{array}{c}2.8 \\
9\end{array}$ & $\begin{array}{c}0.5 \\
3\end{array}$ & $\begin{array}{c}23 \\
3\end{array}$ & $\begin{array}{c}24 . \\
3\end{array}$ & $\begin{array}{c}11 \\
3\end{array}$ & $\begin{array}{c}9.4 \\
6\end{array}$ & $\begin{array}{c}1.4 \\
0\end{array}$ & $\begin{array}{c}13 \\
7\end{array}$ & 1.4 & 1 & 0.9 & 1 & 5 & $\begin{array}{c}0.3 \\
9\end{array}$ \\
\hline 55 & & 200 & $\begin{array}{c}15 \\
1\end{array}$ & $\begin{array}{c}2.6 \\
7\end{array}$ & $\begin{array}{c}0.4 \\
6\end{array}$ & $\begin{array}{c}62 \\
6\end{array}$ & $\begin{array}{c}21 . \\
4\end{array}$ & $\begin{array}{c}10 \\
9\end{array}$ & $\begin{array}{c}7.7 \\
8\end{array}$ & $\begin{array}{c}3.6 \\
7\end{array}$ & $\begin{array}{c}12 \\
4\end{array}$ & 1.3 & 1 & 0.9 & 1 & 4.7 & $\begin{array}{c}0.3 \\
3\end{array}$ \\
\hline 59 & & 30 & 84 & $\begin{array}{c}0.4 \\
7\end{array}$ & $\begin{array}{c}0.0 \\
7\end{array}$ & $\begin{array}{l}17 \\
43\end{array}$ & $\begin{array}{c}10 . \\
8\end{array}$ & 20 & $\begin{array}{c}2.2 \\
6\end{array}$ & $\begin{array}{c}2.3 \\
5\end{array}$ & $\begin{array}{c}17 \\
4\end{array}$ & 1.2 & 1 & 0.9 & 1.3 & 7 & $\begin{array}{c}0.7 \\
4\end{array}$ \\
\hline 62 & & 200 & $\begin{array}{c}19 \\
0\end{array}$ & $\begin{array}{c}2.3 \\
0\end{array}$ & $\begin{array}{c}0.3 \\
3\end{array}$ & $\begin{array}{c}64 \\
4\end{array}$ & $\begin{array}{c}20 . \\
2\end{array}$ & 88 & $\begin{array}{c}6.9 \\
7\end{array}$ & $\begin{array}{c}2.4 \\
4\end{array}$ & $\begin{array}{c}12 \\
9\end{array}$ & 1.4 & 1 & 0.9 & 1.1 & 5.4 & $\begin{array}{c}0.3 \\
8\end{array}$ \\
\hline
\end{tabular}


Table 6. $\mathrm{CaCO}_{3}, \mathrm{C}_{\text {org }}$ and nitrogen content (\%) and their isotopic composition (\%o) for the sediment samples

\begin{tabular}{|c|c|c|c|c|c|c|c|c|}
\hline Stn. No & stations & $\begin{array}{l}\text { depth } \\
\text { (m) }\end{array}$ & $\mathrm{CaCO}_{3} \%$ & $\mathrm{C}_{\text {org }} \%$ & N\% & $\begin{array}{l}\mathrm{C} / \mathrm{N} \\
\text { molar }\end{array}$ & $\delta^{13} \mathrm{C} \%$ & $\delta^{15} \mathrm{~N} \%$ o \\
\hline 1 & \multirow{2}{*}{$\begin{array}{l}\text { CAPE } \\
\text { COM }\end{array}$} & 30 & 76.3 & 0.13 & 0.02 & 7.6 & -19 & 7.1 \\
\hline 3 & & 100 & 86.2 & 0.83 & 0.09 & 10.8 & -20.3 & 6.4 \\
\hline 8 & \multirow[b]{2}{*}{ KOLLAM } & 30 & 6.6 & 1.48 & 0.18 & 9.6 & -20.6 & 6.3 \\
\hline 11 & & 100 & 74.2 & 0.61 & 0.07 & 10.2 & -19.9 & 5.9 \\
\hline 14 & \multirow[b]{3}{*}{$\mathrm{KOCHI}$} & 50 & 18.9 & 0.43 & 0.04 & 12.5 & -21.1 & 5.4 \\
\hline 15 & & 100 & 60.7 & 0.79 & 0.09 & 10.2 & -20.1 & 5.5 \\
\hline 16 & & 200 & 51.8 & 0.86 & 0.1 & 10.0 & -19.9 & 5.3 \\
\hline 17 & \multirow[b]{2}{*}{ CAL } & 30 & 3.1 & 3.51 & 0.37 & 11.1 & -21.5 & 6.3 \\
\hline 19 & & 100 & 29.2 & 0.67 & 0.07 & 11.2 & -20.4 & 5.6 \\
\hline 21 & \multirow[b]{4}{*}{ KANNUR } & 200 & 63.2 & 1.33 & 0.13 & 11.9 & -20.3 & 5.7 \\
\hline 22 & & 100 & 52.3 & 1.08 & 0.11 & 11.5 & -20.6 & 6.2 \\
\hline 24 & & 50 & 21.2 & 0.92 & 0.11 & 9.8 & -21 & 4.8 \\
\hline 25 & & 30 & 0.5 & 3.45 & 0.35 & 11.5 & -21.6 & 6.7 \\
\hline 26 & \multirow[b]{2}{*}{ MNG } & 30 & 5.4 & 3.01 & 0.3 & 11.7 & -21.7 & 6.2 \\
\hline 29 & & 200 & 44.7 & 0.77 & 0.08 & 11.2 & -20.6 & 4.6 \\
\hline 31 & \multirow[b]{2}{*}{ BHAT } & 100 & 65.3 & 0.85 & 0.08 & 12.4 & -21.1 & 5.5 \\
\hline 33 & & 50 & 41.4 & 0.34 & 0.03 & 13.2 & -21.4 & 5 \\
\hline 35 & \multirow[b]{4}{*}{ GOA } & 30 & 2.1 & 3.02 & 0.33 & 10.7 & -21.4 & 7.1 \\
\hline 36 & & 50 & 11.5 & 3.44 & 0.38 & 10.6 & -20.7 & 7.3 \\
\hline 37 & & 70 & 61.6 & 1.15 & 0.12 & 11.2 & -20.8 & 6.8 \\
\hline 38 & & 100 & 63.5 & 1.99 & 0.19 & 12.2 & -20.9 & 6.4 \\
\hline 40 & \multirow[b]{2}{*}{ RAT } & 30 & 6.8 & 2.37 & 0.25 & 11.1 & -20.3 & 7.1 \\
\hline 41 & & 50 & 13.1 & 3.25 & 0.35 & 10.8 & -20.4 & 7.5 \\
\hline
\end{tabular}




\begin{tabular}{|c|c|c|c|c|c|c|c|c|}
\hline 42 & & 75 & 59.3 & 1.8 & 0.16 & 13.1 & -21.3 & 7 \\
\hline 43 & & 100 & 84.3 & 0.72 & 0.07 & 12.0 & -20.4 & 6.7 \\
\hline 45 & & 30 & 5.7 & 1.82 & 0.19 & 11.2 & -20 & 7.1 \\
\hline 46 & & 50 & 37.1 & 1.7 & 0.19 & 10.4 & -20.6 & 7 \\
\hline 47 & MUM & 100 & 75 & 1.19 & 0.12 & 11.6 & -20.7 & 7.5 \\
\hline 50 & & 100 & 93.1 & 0.28 & 0.03 & 10.9 & -20.5 & 8.7 \\
\hline 52 & & 80 & 21.9 & 1.28 & 0.14 & 10.7 & -19.3 & 6.4 \\
\hline 54 & VER & 30 & 9.2 & 0.72 & 0.06 & 14.0 & -18.5 & 6 \\
\hline 55 & & 200 & 20.8 & 1.65 & 0.17 & 11.3 & -20.2 & 7.6 \\
\hline 56 & & 100 & 26.2 & 2.5 & 0.27 & 10.8 & -20.3 & 7.5 \\
\hline 58 & POR & 30 & 12.4 & 1.13 & 0.15 & 8.8 & -18.2 & 6.6 \\
\hline 59 & & 30 & 75 & 0.24 & 0.04 & 7.0 & -19.1 & 9.1 \\
\hline 60 & & 50 & 10.4 & 0.65 & 0.11 & 6.9 & -19.4 & 6.7 \\
\hline 62 & DWA & 200 & 29 & 2.66 & 0.31 & 10.0 & -20.3 & 7.7 \\
\hline
\end{tabular}

